\title{
Hydrogenation of aqueous nitrate and nitrite with
} ruthenium catalysts

\author{
Xiangchen Huo, ${ }^{1}$ Daniel J. Van Hoomissen, ${ }^{2}$ Jinyong Liu, ${ }^{1}$ Shubham Vyas, ${ }^{2}$ Timothy J. Strathmann ${ }^{1 *}$ \\ ${ }^{1}$ Department of Civil and Environmental Engineering and ${ }^{2}$ Department of Chemistry and Geochemistry, \\ Colorado School of Mines, Golden, Colorado 80401, United States \\ *Corresponding author: phone: +1-303-384-2226, E-mail: strthmnn@mines.edu
}

Abstract - Historically, development of catalysts for treatment of nitrate-contaminated water has focused on supported Pd-based catalysts, but high costs of the Pd present a barrier to commercialization.

As part of an effort to develop lower cost hydrogenation catalysts for water treatment applications, we investigated catalysts incorporating Ru with lower cost. Pseudo-first-order rate constants and turnover frequencies were determined for carbon- and alumina-supported Ru and demonstrated Ru's high activity for hydrogenation of nitrate at ambient temperature and $\mathrm{H}_{2}$ pressure. Ex situ gas pretreatment of the catalysts was found to enhance nitrate reduction activity by removing catalyst surface contaminants and exposing highly reducible surface $\mathrm{Ru}$ oxides. Ru reduces nitrate selectively to ammonium, and no aqueous nitrite intermediate is observed during reactions. In contrast, reactions initiated with nitrite yield a mixture of two endproducts, with selectivity shifting from ammonium towards $\mathrm{N}_{2}$ at increasing initial aqueous nitrite concentrations. Experimental observation and Density Functional Theory calculations 
24 together support a reaction mechanism wherein sequential hydrogenation of nitrate to nitrite and NO is

25 followed by parallel pathways involving the adsorbed NO: (1) sequential hydrogenation to ammonium,

26 and (2) N-N coupling with aqueous nitrite followed by hydrogenation to the detected $\mathrm{N}_{2} \mathrm{O}$ intermediate

27 and $\mathrm{N}_{2}$ endproduct. These findings open the door to development of alternative catalysts for purifying

28 and recovering nutrients from nitrate-contaminated water sources, and insights into the controlling

29 surface reaction mechanisms can guide rational design efforts aimed at increasing activity and tuning

30 endproduct selectivity.

31

32 Keywords: Ruthenium catalysts, nitrate reduction, catalyst pretreatment, isotope labeling, density

33 functional theory

34 


\section{1. Introduction}

36 Nitrate contamination of drinking water sources is among the greatest public health threats around the

37 world [1]. Nitrate concentrations exceeding health-based standards are routinely detected in drinking

38 water sources due to excess fertilizer applications and release of incompletely treated industrial and

39 domestic wastewater [2-4]. The growing contamination of drinking water sources raises health concerns

40 because nitrate can be transformed into hazardous chemicals, including nitrite, which causes

41 methemoglobinemia (i.e., blue baby syndrome), and potentially carcinogenic nitrosamines [5, 6]. As a

42 result, there is great interest in the development of efficient, robust and low-cost technologies for

43 treating nitrate-contaminated water.

44 Several technologies are available to separate nitrate from water, including ion exchange $[7,8]$, high

45 pressure membrane filtration [9], and electrodialysis [10], and have demonstrated their effectiveness in

46 full-scale practice [2, 11]. The principal drawback of these systems is the production of a nitrate

47 concentrate stream that requires further treatment before disposal $[12,13]$. Biological denitrification is

48 widely used for the treatment of municipal and industrial wastewater, but concerns about pathogen

49 introduction, the need for costly organic carbon amendments and potential residuals, and biological

50 sludge production have limited application for drinking water treatment [14, 15]. More recently,

51 chemical reduction of nitrate has been increasingly explored. Zerovalent metals, including iron [16],

52 aluminum [17], and magnesium [18], stoichiometrically couple nitrate reduction with metal corrosion, 
53 but reactions are hindered by the formation of oxide surface coatings, and the need to constantly

54 replenish the metals as reducing equivalents are consumed creates operational challenges.

55 As an alternative to stoichiometric metal reductants, our team and others have been investigating the

56 application of metal hydrogenation catalysts that couple nitrate reduction with $\mathrm{H}_{2}$ oxidation [7, 19-23].

57 Nitrate can be transformed into two endproducts with different $\mathrm{H}_{2}$ and acidity requirements:

$$
\begin{aligned}
& \mathrm{NO}_{3}^{-}+2.5 \mathrm{H}_{2}+\mathrm{H}^{+} \stackrel{\text { catalyst }}{\longrightarrow} 0.5 \mathrm{~N}_{2}+3 \mathrm{H}_{2} \mathrm{O} \\
& \mathrm{NO}_{3}^{-}+4 \mathrm{H}_{2}+2 \mathrm{H}^{+} \stackrel{\text { catalyst }}{\longrightarrow} \mathrm{NH}_{4}^{+}+3 \mathrm{H}_{2} \mathrm{O}
\end{aligned}
$$

58 Because the metals are acting as catalysts rather than stoichiometric reactants, they are not consumed in

59 the process or generate a secondary solid waste stream that requires disposal. $\mathrm{H}_{2}$ is an inexpensive

60 electron donor that has lower life cycle environmental impacts than organic electron donors applied in

61 most biological denitrification processes [24]. To date, most work has focused on the development of

62 nitrate and nitrite treatment processes employing supported Pd-based catalysts [13, 25, 26]. Pd catalysts

63 are highly effective in converting nitrite, the first daughter product of nitrate reduction, to harmless $\mathrm{N}_{2}$

64 gas at an incomparable rate [27-29], but monometallic Pd catalysts show little reactivity with nitrate [30,

65 31]. Deposition of a second "promoter" metal (e.g., $\mathrm{Cu}, \mathrm{In}, \mathrm{Sn}$ ) together with Pd is typically required to

66 facilitate reduction of nitrate to nitrite [23, 31, 32]. A large body of literature has reported on aqueous

67 nitrate reduction with Pd-based bimetallic catalysts [20, 30, 31, 33-37], and our current understanding of

68 metal-catalyzed nitrate hydrogenation mechanisms has been limited to reactions occurring with these

69 materials. The prevailing reaction pathway follows a two-step process depicted in Scheme 1: (1) 
70 hydrogenation of nitrate to nitrite on bimetallic clusters followed by (2) further hydrogenation of nitrite

71 on Pd sites to a mixture of $\mathrm{N}_{2}$ and ammonium stable endproducts, the net processes being reflected by

72 Eqs. (1-2) [22, 35, 38-40]. The proposed sequential reduction pathway is supported by the observation

73 of nitrite as a transient reaction intermediate [23,33], increasing with $\mathrm{pH}$ as the rate of Pd-catalyzed

74 nitrite reduction decreases [39, 41], and isotope labeling experiments showing Pd-catalyzed reduction of

75 NO to the same mixture of endproducts and selective conversion of $\mathrm{N}_{2} \mathrm{O}$ to $\mathrm{N}_{2}$ [22]. The distribution of

76 endproducts, presumed to be controlled by the Pd-catalyzed reactions of nitrite or its daughter products

77 (e.g., adsorbed NO), has been reported to vary with catalyst composition [31], metal nanoparticle size

78 [42], support [43], and solution $\mathrm{pH}[44]$.

79 Although years of effort have been invested in improving the activity, endproduct selectivity, and

80 long-term stability of Pd-based bimetallic catalysts [31, 45] (and to a lesser extent Pt-based catalysts [36,

$8146]$ ), deployment of practical catalytic treatment systems remains limited, in large part, due to high costs

82 of Pd [47]. Precious metal-free catalysts based on Ni have been explored [15, 48, 49], but instability in

83 aqueous matrices [50], and serious concerns about the associated leaching of dissolved $\mathrm{Ni}^{2+}$ [51] and the

84 pyrophoric nature of highly active Raney Ni [52] have limited further development efforts.

85 As a result of the low nitrate and nitrite reduction activity reported in early catalyst screening studies

86 [27, 28], Ru hydrogenation catalysts have been largely overlooked for such applications. However, a

87 renewed examination of the application of Ru-based catalysts is warranted because of the historically

88 much lower price of Ru in comparison to Pd and Pt [47] as well as the metal's documented catalytic 
89 activity for a diverse range of reactions, including hydrogenation, hydrodeoxygenation and

90 hydrodechlorination reactions [53, 54]. In addition, work on electrochemical reduction of nitrate (in

91 acidic media) has shown that $\mathrm{Ru}$ electrodes exhibit higher activity than $\mathrm{Pt}, \mathrm{Pd}$ and $\mathrm{Ir}$ electrodes [55].

92 After recently screening a range of metal catalysts as alternatives to Pd for reduction of oxyanion

93 pollutants [56], this contribution focuses on a renewed evaluation of the kinetics and mechanisms of

94 nitrate and nitrite reduction by supported $\mathrm{Ru}$ catalysts. Reaction kinetics, product distribution analysis,

95 and catalyst characterization studies are combined with Density Functional Theory (DFT) calculations to

96 improve our understanding of interaction between nitrate (and nitrite) and $\mathrm{Ru}$ metal surfaces and

97 elucidate the origin of endproduct selectivity.

98

99 2. Materials and methods

\section{$100 \quad$ 2.1. Catalysts}

101 A full listing of chemical reagents is provided in Supporting Information (SI; Section S1). Ru and Pd 102 catalysts immobilized on carbon and alumina supports (nominal $5 \mathrm{wt} \%$ metal) were purchased from

103 Sigma-Aldrich. Unless otherwise noted, the as-received $\mathrm{Ru}$ and $\mathrm{Pd}$ catalysts were pretreated ex situ in

104 flowing $\mathrm{H}_{2}$ at $350^{\circ} \mathrm{C}$ for $2 \mathrm{~h}$ prior to use in aqueous oxyanion reduction experiments. The only exception

105 to this was for experiments specifically examining the effects of different ex situ pretreatments (see

106 section 3.2), wherein the as-received catalysts (no pretreatment), catalysts pretreated ex situ in flowing

$107 \mathrm{~N}_{2}$ at $350^{\circ} \mathrm{C}$ for $2 \mathrm{~h}$, and catalysts pretreated ex situ in flowing $\mathrm{H}_{2}$ as mentioned above were compared. 
108 No precautions were taken following pretreatment to avoid surface passivation upon exposure to air.

109 Bimetallic $\mathrm{Pd}-\mathrm{Cu} / \mathrm{C}, \mathrm{Ru}-\mathrm{Cu} / \mathrm{C}$, and $\mathrm{Ru}-\mathrm{In} / \mathrm{C}$ catalysts were prepared by incipient wetness impregnation

110 [57] of $1 \mathrm{wt} \%$ of $\mathrm{Cu}\left(\right.$ as $\left.\mathrm{Cu}\left(\mathrm{NO}_{3}\right)_{2} \cdot 3 \mathrm{H}_{2} \mathrm{O}\right)$ or $\mathrm{In}\left(\operatorname{as~} \mathrm{In}\left(\mathrm{NO}_{3}\right)_{3} \cdot 3 \mathrm{H}_{2} \mathrm{O}\right)$ on as-received commercial $\mathrm{Pd} / \mathrm{C}$ and

$111 \mathrm{Ru} / \mathrm{C}$, respectively, followed by air drying at $110^{\circ} \mathrm{C}$ for $12 \mathrm{~h}$ and $\mathrm{H}_{2}$ at $350{ }^{\circ} \mathrm{C}$ for $2 \mathrm{~h}$.

112 Catalysts were extensively characterized, including metal content (inductively coupled

113 plasma-optical emission spectrometry, ICP-OES), specific surface area and average pore diameter of the

114 support materials $\left(\mathrm{N}_{2}\right.$ physisorption), metal dispersion (the percentage of $\mathrm{Ru}$ or Pd atoms present on the

115 clean surface of the immobilized metal nanoparticles, $\mathrm{CO}$ chemisorption), active surface (the percentage

116 of $\mathrm{Ru}$ or $\mathrm{Pd}$ atoms accessible to reactants under simulated in situ conditions, $\mathrm{CO}$ chemisorption),

117 morphology and size of the metal nanoparticles (transmission electron microscopy and high-angle

118 annular dark-field-scanning transmission electron microscopy, TEM and HAADF-STEM), Ru

119 reducibility $\left(\mathrm{H}_{2}\right.$ temperature-programmed reduction, $\left.\mathrm{H}_{2} \mathrm{TPR}\right)$, and long-range structural order (X-ray

120 diffraction, XRD). Details of each methodology are provided in SI Section S2.

\section{$121 \quad$ 2.2. Nitrate and nitrite reduction kinetics}

122 Aqueous nitrate and nitrite reduction kinetics were measured in an open semi-batch system under

123 continuous $\mathrm{H}_{2}$ sparging $\left(1 \mathrm{~atm}, 40 \mathrm{~mL} \cdot \mathrm{min}^{-1}\right)$ at constant temperature $\left(25 \pm 0.5{ }^{\circ} \mathrm{C}\right) . \mathrm{A} 250 \mathrm{~mL}$

124 three-neck reactor was filled with $150 \mathrm{~mL}$ deionized water and predetermined mass of catalyst. The

125 suspension was sonicated for $5 \mathrm{~min}$ and sparged with $\mathrm{H}_{2}$ gas for $30 \mathrm{~min}$ before introducing a small

126 volume of $\mathrm{NaNO}_{3}$ or $\mathrm{NaNO}_{2}$ stock solution to initiate the reaction. Reaction progress was monitored by 
127 periodic collection of suspension aliquots $(1.5 \mathrm{~mL})$ that were immediately filtered $(0.22 \mu \mathrm{m}$ cellulose 128 acetate) to remove catalyst particles and quench reactions prior to analysis by ion chromatography $\left(\mathrm{NO}_{3}{ }^{-}\right.$

129 and $\left.\mathrm{NO}_{2}{ }^{-}\right)$and colorimetric assay $\left(\mathrm{NH}_{4}{ }^{+}\right)$. The suspension was mixed by a Teflon-coated magnetic stir 130 bar at $700 \mathrm{rpm}$. Solution $\mathrm{pH}$ was maintained by $\mathrm{HCl}$ addition from an automatic $\mathrm{pH}$-stat (Radiometer

131 TitraLab 854). Catalyst activity was assessed by quantifying initial mass-normalized pseudo-first-order

132 rate constants $\left(k_{0}, \mathrm{~L} \cdot \mathrm{g}_{\mathrm{Ru} / \mathrm{Pd}}{ }^{-1} \cdot \mathrm{min}^{-1}\right)$ and turnover frequencies $\left(\mathrm{TOF}_{0}, \mathrm{~min}^{-1}\right)$, defined as the number of

133 nitrate or nitrite ions reduced per active surface site per minute. The active surface was estimated from

$134 \mathrm{CO}$ chemisorption measurement using an assumed 1:1 CO:Metal adsorption stoichiometry [58, 59].

135 Additional details of the procedures for kinetics parameter calculations and aqueous analytical

136 measurements are provided in SI Sections S3 and S4, respectively. A catalyst re-use experiment was

137 carried out to evaluate the stability of Ru/C. After a semi-batch reaction was complete, the catalyst solid 138 was collected on a filter (glass fiber filter; EMD Millipore), washed with deionized water several times, 139 and vacuum dried at $65{ }^{\circ} \mathrm{C}$ overnight before re-suspending in water for the subsequent semi-batch 140 reaction. The catalyst was also re-characterized after completion of the re-use experiment.

\section{$141 \quad$ 2.3. Isotope labeling experiments}

142 Nitrogen mass balances and endproduct distributions were quantified using closed-bottle batch 143 experiments with the aid of ${ }^{15} \mathrm{~N}$-labeled nitrate and nitrite salts to avoid the interference from 144 atmospheric ${ }^{14} \mathrm{~N}_{2}$ during mass spectrometry measurement of the $\mathrm{N}_{2}$ endproduct [22]. A $160 \mathrm{~mL}$ serum 145 bottle with $75 \mathrm{~mL}$ of an organic buffer, 4-morpholineethanesulfonic acid (MES) (pH 5.5, $40 \mathrm{mM}$ ), a 
146 predetermined mass of catalyst, and a Teflon-coated magnetic stir bar was sealed by a $1.0 \mathrm{~cm}$-thick 147 rubber stopper held in place by an Al crimp cap. Experiments were conducted at ambient temperature $148\left(21 \pm 1^{\circ} \mathrm{C}\right)$ and suspensions were mixed in the same manner as the semi-batch experiments. The reactor 149 was sparged with $\mathrm{H}_{2}$ for 30 min to saturate the headspace and solution before introducing the target 150 oxyanion pollutant. A $\mathrm{H}_{2}$-sparged stock solution of $\mathrm{Na}^{15} \mathrm{NO}_{3}$ or $\mathrm{Na}^{15} \mathrm{NO}_{2}$ was then added to the reactor 151 to initiate the reaction, and $1.5 \mathrm{~mL}$ aqueous aliquots were withdrawn by syringe through the gas-tight 152 septa to monitor disappearance of the parent reactant and the evolution of aqueous intermediates and 153 products. Headspace samples $(0.1 \mathrm{~mL})$ were collected separately and immediately analyzed for labeled 154 gaseous intermediates and products $\left({ }^{15} \mathrm{NO},{ }^{15} \mathrm{~N}_{2} \mathrm{O}\right.$, and $\left.{ }^{15} \mathrm{~N}_{2}\right)$ by gas chromatography-mass spectrometry 155 (GC-MS, details in SI). Headspace gases were assumed to be maintained in equilibrium with the 156 aqueous phase at all times [60], which was supported by good nitrogen mass balance closure. Analyte 157 values in these experiments are reported in moles of nitrogen because products include both liquid and 158 gas species as well as both mono- and diatomic nitrogen species. The total mass of $\mathrm{H}_{2}$ initially added to 159 the sealed batch reactor $(\sim 3.4 \mathrm{mmol})$ was in significant excess of the stoichiometric requirement for the 160 complete reduction of the added $\mathrm{NO}_{3}{ }^{-}$to $\mathrm{NH}_{4}{ }^{+}(\sim 0.5 \mathrm{mmol})$.

\section{2.4. Computational methods}

162 DFT calculations of $\mathrm{N}$-containing species associated with $\mathrm{Ru}$ metal surfaces were performed with 163 the Gaussian 09 suite of programs [61]. $\mathrm{A} \mathrm{Ru} 18$ metal cluster structure was used to model Ru catalysts 164 based on the work of Aguilera-Granja et al. [62] and Zhang et al. [63]. It was shown that Ru and Rh 
165 clusters with fewer than 20 atoms adopt simple cubic or distorted cubic structure. Geometry 166 optimizations of Ru clusters were completed at the PBE0 [64] level of theory with the Lanl2DZ basis set $167[65,66]$. The core electrons of $\mathrm{Ru}$ atoms were modeled using the SDD effective core pseudo-potential $168[65,67]$. The PBE0 functional was shown to be a reliable method in predicting both the properties and 169 reactions involved with transition metals and metal clusters [68], including $\mathrm{Ru}$, with accuracies 170 approaching or exceeding other functionals commonly utilized in solid state systems [69].

171 Small molecule (i.e., nitrate, nitrite, and other reacting species) adsorption to the metal clusters were 172 optimized at the PBE0/Lanl2DZ(Ru)/6-31+G(d,p)(H, N, O) level of theory. The geometry optimization 173 of small molecules was performed with the Ru cluster fixed. Thermodynamic barriers were calculated 174 from the bottom of the well energies, as thermodynamic corrections would be an unnecessary addition 175 of error due to the frozen bond constraints given to the metal atom centers. The integral equation 176 formalism polarizable continuum model (IEF-PCM) [70] was used to implicitly model the aqueous 177 environment and was present in all optimizations and single point energy calculations. To correct for 178 spin contamination for unpaired electron intermediates, single point energies utilizing a restricted open 179 shell (RO) wavefunction were calculated at the ROPBE0/Lanl2DZ(Ru)/6-31+G(d,p)(H, N, O) level of 180 theory. When multiple conformations of adsorbed $\mathrm{N}$-containing species were possible, the complexes 181 with the lowest energy were chosen for the calculation of reaction energies. 


\section{Results and discussion}

\subsection{Catalytic nitrate reduction}

Fig. 1 shows the catalytic reduction of aqueous nitrate on $\mathrm{Ru} / \mathrm{C}$ in comparison to monometallic $\mathrm{Pd} / \mathrm{C}$ and bimetallic Pd-Cu/C. In contrast to an earlier report of limited nitrate reactivity with Ru catalysts [28], these experiments demonstrate that $\mathrm{Ru}$ is an effective catalyst, exhibiting much greater activity than monometallic $\mathrm{Pd} / \mathrm{C}$ of the same mass loading and similar activity to $\mathrm{Pd} / \mathrm{C}$ after immobilization of $1 \mathrm{wt} \%$

$\mathrm{Cu}$ as secondary promoter metal. For all three catalysts shown in Fig. 1, nitrate reduction kinetics follow a pseudo-first-order rate law over at least the first reaction half-life, and model fits of the data shown yield Ru- and Pd-mass-normalized pseudo-first-order rate constants of $4.13 \pm 0.30 \mathrm{~L} \cdot \mathrm{g}_{\mathrm{Ru}}{ }^{-1} \cdot \mathrm{min}^{-1}, 0.46 \pm$

The rate constants are calculated using the metal loading reported in Table 1. Control experiments conducted under continuous $\mathrm{N}_{2}$ sparging (catalyst suspensions sparged with $\mathrm{H}_{2}$ for 30 min followed by

$\mathrm{N}_{2}$ for another 60 min to displace $\mathrm{H}_{2}$ before introducing nitrate to the reactor) show negligible loss of nitrate, demonstrating minimal adsorption onto the catalyst supports. Since the catalysts were subjected negligible direct reduction of nitrate by the metallic Ru or Pd phases. Initial rates of nitrate reduction

vary linearly with catalyst loading between 0 and $0.5 \mathrm{~g} \cdot \mathrm{L}^{-1} \mathrm{Ru} / \mathrm{C}$ (Fig. S2), indicating that catalyst suspensions were well mixed and external mass transfer limitations for the reactants (nitrate and $\mathrm{H}_{2}$ ) 
201 S5) is $<<1$, indicating that the internal mass transfer within the porous catalyst support particles is also 202 not rate limiting. Ru/C exhibited good stability in batch re-use experiments, with activity decreasing $203<5 \%$ after each run (Fig. S3). Dissolved Ru measured in the supernatant of catalyst suspensions was 204 below $1 \mathrm{ppb}$, demonstrating negligible leaching of the active metal. Electron microscopy of the catalyst 205 collected following repeated re-use shows no agglomeration or growth of Ru nanoparticles (Fig. 3a and 206 3b). The small drop in activity observed between runs is speculated to be caused by material loss during 207 the filtration recovery protocol used between runs. Immobilization of secondary promoter metals ( $1 \mathrm{wt} \%$ $208 \mathrm{Cu}$ and $\mathrm{In}$ ) that have been reported to enhance nitrate reduction activity for Pd catalysts did not enhance $209 \mathrm{Ru} / \mathrm{C}$ reactions with nitrate (data not shown).

210 Reductive transformation of nitrate, rather than adsorption or other transformation process, is also 211 confirmed by the good nitrogen mass balance closure (Fig. 2a) observed using closed-bottle batch 212 experiments with the aid of a ${ }^{15} \mathrm{~N}$-labeled nitrate salt that eliminated potential artifacts from atmospheric 213 contamination during analysis of $\mathrm{N}_{2}$. For $\mathrm{Ru} / \mathrm{C}$, nitrate is converted selectively to ammonium without 214 producing any detectable ${ }^{15} \mathrm{~N}_{2}$ by GC-MS analysis, and none of the transient aqueous or gaseous 215 intermediates typically observed for Pd-based catalysts (nitrite and $\mathrm{N}_{2} \mathrm{O}$ ) $[39,71]$ are detected.

216 The effect of solution $\mathrm{pH}$ on nitrate reactions with $\mathrm{Ru} / \mathrm{C}$ was evaluated in the open semi-batch 217 systems using $\mathrm{HCl} / \mathrm{NaOH}$ to maintain $\mathrm{pH}$ (Fig. S4). Ru-mass-normalized pseudo-first-order rate 218 constants are relatively constant between $\mathrm{pH} 5-8$, but decrease significantly at lower and higher $\mathrm{pH}$ 219 conditions. Since gaseous nitrogen species cannot be measured in the open semi-batch reactors sparged 
continuously with $\mathrm{H}_{2}$, a stringent mass balance analysis of endproducts was not feasible. However,

221 ammonium product yields reached $\geq 90 \%$ of the initial nitrate concentrations for all $\mathrm{pH}$ conditions, 222 consistent with the high selectivity measured in the closed reactor experiment conducted at pH $5.5 \mathrm{using}$ $223{ }^{15}$ N-labeled species (Fig. 2a).

224 Comparison between metal dispersion and active surface in Table 1 suggests that 30 min of $\mathrm{H}_{2}$ 225 treatment at $25{ }^{\circ} \mathrm{C}$ is sufficient to re-reduce a large fraction of any surface oxides that might form upon 226 air passivation of ex situ $\mathrm{H}_{2}$ pretreated catalysts. Despite the heterogeneity in particle morphology (Fig. 2273 and Fig. S5) and an assumed 1:1 CO:Metal adsorption stoichiometry for all catalysts irrespective of 228 metal particle size and support, metal dispersion values derived from CO chemisorption analysis [73] 229 are reasonably consistent with particle sizes observed by electron microscopy (Table 1). The rate 230 constants for monometallic catalysts correspond to initial turnover frequencies $\left(\mathrm{TOF}_{0}\right)$ of $2.1 \pm 0.2 \mathrm{~min}^{-1}$ 231 for $\mathrm{Ru} / \mathrm{C}$ and $0.42 \pm 0.07 \mathrm{~min}^{-1}$ for $\mathrm{Pd} / \mathrm{C}$ based on active metal surface. $\mathrm{TOF}_{0}$ of nitrate reduction on $232 \mathrm{Ru} / \mathrm{C}$ is five times greater than that of $\mathrm{Pd} / \mathrm{C}$. The higher reactivity of monometallic $\mathrm{Ru} / \mathrm{C}$ than $\mathrm{Pd} / \mathrm{C}$ is 233 especially noteworthy because the Pd/C reactivity observed in Fig. 1 is actually much greater than that 234 reported in earlier studies that found either no reaction with nitrate or a very low extent of reaction [30, 235 31, 56, 74-76]. Trawczyński et al. [71] calculated $\mathrm{TOF}_{0}$ of nitrate reduction on an in-house prepared $236 \mathrm{Pd} / \mathrm{C}$ catalyst to be $\sim 0.03 \mathrm{~min}^{-1}$, which is one order-of-magnitude lower than the $\mathrm{TOF}_{0}$ calculated from 237 data for $\mathrm{Pd} / \mathrm{C}$ in Fig. 1. Considering that deionized water $\left(\geqslant 18 \mathrm{M} \Omega \cdot \mathrm{cm}^{-1}\right)$ was used for all experiments 238 and known promoter metals for $\mathrm{Pd}$ catalyst including $\mathrm{Cu}$, In, and $\mathrm{Sn}$ were not detected by Energy 
239 Dispersive X-ray spectroscopy analysis of $\mathrm{Pd} / \mathrm{C}$, we believe that the higher activity of $\mathrm{Pd} / \mathrm{C}$ observed

240 here is not due to promoter metal contamination from solution or surface residues present following 241 synthesis of catalyst support.

242 The nature of active sites in $\mathrm{Pd}-\mathrm{Cu}$ bimetallic catalysts is not well understood or characterized.

243 Although it is technically possible to estimate surface atoms by $\mathrm{H}_{2}$ chemisorption [23, 77], we believe

244 the measurement does not represent bimetallic sites and chose not to calculate the $\mathrm{TOF}_{0}$ for nitrate

245 reduction on $\mathrm{Pd}-\mathrm{Cu} / \mathrm{C}$ or compare the intrinsic activity between $\mathrm{Ru}$ and $\mathrm{Pd}-\mathrm{Cu}$ bimetallic surface.

246 However, it can be seen from Table $\mathrm{S} 1$ that the $\mathrm{Pd}-\mathrm{Cu} / \mathrm{C}$ catalyst prepared for comparison in this study

247 exhibits activity on a Pd mass-normalized basis that is comparable with other studies that focused in

248 greater depth on the activity and mechanism of such bimetallic catalysts.

\subsection{Effect of pretreatment on nitrate reduction activity}

250 The high activity of $\mathrm{Ru} / \mathrm{C}$ with nitrate observed here in comparison with earlier reports warrants 251 further examination. Several studies have documented that the reactivity of supported metal 252 nanoparticles is influenced by nanoparticle size and shape, chemical state, support properties and 253 metal-support interaction, which are subject to the starting materials (support material and metal 254 precursor), synthesis methods and activation steps [36, 78]. The present study used commercially 255 produced catalysts to take advantage of materials with optimized industrial production and adapted for 256 large scale applications. However, the high reactivity with aqueous nitrate of Ru catalysts was 257 demonstrated with the catalyst pretreated ex situ in flowing $\mathrm{H}_{2}$ at $350{ }^{\circ} \mathrm{C}$ for $2 \mathrm{~h}$ prior to use, and the 
258 as-received $\mathrm{Ru} / \mathrm{C}$ and $\mathrm{Ru} / \mathrm{Al}_{2} \mathrm{O}_{3}$ show low or no activity. To further characterize the effects of ex situ 259 pretreatment on catalyst activity, we had commercial $\mathrm{Ru} / \mathrm{C}, \mathrm{Ru} / \mathrm{Al}_{2} \mathrm{O}_{3}, \mathrm{Pd} / \mathrm{C}$ and $\mathrm{Pd} / \mathrm{Al}_{2} \mathrm{O}_{3}$ subjected to 260 ex situ heat treatment $\left(350^{\circ} \mathrm{C}, 2 \mathrm{~h}\right)$ in both inert gas $\left(\mathrm{N}_{2}\right)$ and reducing gas $\left(\mathrm{H}_{2}\right)$ and tested of their nitrate 261 reduction activity. The metal mass-normalized pseudo-first-order rate constants for nitrate reduction 262 with these materials are calculated and presented in Fig. 4. Ex situ pretreatment of Ru/C, either with 263 flowing $\mathrm{H}_{2}$ or $\mathrm{N}_{2}$, leads to more than a threefold increase in catalyst activity compared to the as-received 264 catalyst. The effect of pretreatment is most pronounced for $\mathrm{Ru} / \mathrm{Al}_{2} \mathrm{O}_{3}$, in that the catalyst is only active 265 after pretreatment in flowing $\mathrm{H}_{2}$. In comparison, pretreatment has no effect on the activity of $\mathrm{Pd} / \mathrm{C}$. $266 \mathrm{Pd} / \mathrm{Al}_{2} \mathrm{O}_{3}$ exhibited no activity for nitrate reduction irrespective of catalyst pretreatment.

267 A battery of characterization analyses was conducted to rationalize the dramatic influence of ex situ 268 pretreatment on $\mathrm{Ru}$ catalysts. XRD scan of $\mathrm{Ru} / \mathrm{C}$ (Fig. 5a) shows mainly peaks associated with 269 crystalline carbon phases, but no significant peaks for Ru metal (ca. $44^{\circ}$ and $38^{\circ}$, JCPDS card No. 270 06-0663) or $\mathrm{RuO}_{2}$ (ca. $28^{\circ}, 35^{\circ}$ and 54 ${ }^{\circ}$, JCPDS card No. 43-1027), indicating small crystal size below 271 XRD detection limit. The XRD pattern for $\mathrm{Ru} / \mathrm{Al}_{2} \mathrm{O}_{3}$ (Fig. 5b) shows crystalline $\mathrm{RuO}_{2}$ in both the 272 as-received and ex situ $\mathrm{N}_{2}$ pretreated materials, but these features disappear and new features 273 characteristic of crystalline $\mathrm{Ru}$ metal appear in the $\mathrm{H}_{2}$ pretreated $\mathrm{Ru} / \mathrm{Al}_{2} \mathrm{O}_{3}$. For both $\mathrm{Ru} / \mathrm{C}$ and $\mathrm{Ru} / \mathrm{Al}_{2} \mathrm{O}_{3}$ 274 catalysts, the catalyst activity (Fig. 4) roughly correlates with the active Ru surface of catalysts (Table 275 S2), suggesting that catalyst pretreatment increased the Ru surface area active for catalytic reaction. 
Increasing surface area often results from decreased particle size, which is not the case for $\mathrm{Ru} / \mathrm{C}$ in

277 this study. The size distribution of Ru particles in the as-received Ru/C $(1.9 \pm 0.6 \mathrm{~nm}$, Fig. 3c) is not

278 statistically different from that measured following the ex situ $\mathrm{H}_{2}$ pretreatment process $(2.2 \pm 0.8 \mathrm{~nm}$,

279 Fig. 3a). Another possibility is that the Ru catalyst surface in the as-received $\mathrm{Ru} / \mathrm{C}$ is blocked by

280 residues from synthesis, which may be partially or fully removed by the high temperature pretreatment

281 processes. $\mathrm{H}_{2}$ TPR analysis provides evidence to support this hypothesis. The TPR profiles (Fig. 6) of $e x$

282 situ $\mathrm{H}_{2}$ - and $\mathrm{N}_{2}$-pretreated $\mathrm{Ru} / \mathrm{C}$ are similar, with a first reduction peak located between 50 and $55^{\circ} \mathrm{C}$ and

283 a second broad reduction peak above $400{ }^{\circ} \mathrm{C}$. The reduction peak temperature of supported Ru oxides

284 formed during catalyst calcination has been reported to vary between $65^{\circ} \mathrm{C}$ and $185^{\circ} \mathrm{C}[79,80]$. Though

285 the temperature of the first reduction peak observed here falls below this range, the $\mathrm{H}_{2}$ consumption

286 quantified from the peak area (Table S2) is consistent with the theoretical stoichiometry for $\mathrm{H}_{2}$

287 consumption during $\mathrm{RuO}_{2}$ reduction [79]:

$$
\mathrm{RuO}_{2}+2 \mathrm{H}_{2} \rightarrow \mathrm{Ru}+2 \mathrm{H}_{2} \mathrm{O}
$$

288 The Ru oxides formed upon re-oxidation of pretreated Ru upon exposure to ambient air are redox-labile,

289 enabling re-reduction by $\mathrm{H}_{2}$ at $25^{\circ} \mathrm{C}$. The second reduction peak is assigned to the direct reduction of

290 aldehyde, quinone and phenol groups on the carbon support [81]. The TPR profile for as-received Ru/C

291 is markedly different from those of ex situ pretreated Ru/C. A much larger $\mathrm{H}_{2}$ consumption and a dip in

292 the TCD signal match the features of surface species decomposition and desorption, supporting the

293 hypothesis that the as-received catalyst surface is blocked by residues that desorb upon heat pretreatment. 
294 Temperature-programmed desorption study of as-received $\mathrm{Ru} / \mathrm{C}$ and ex situ $\mathrm{H}_{2}$ pretreated $\mathrm{Ru} / \mathrm{C}$ in $\mathrm{Ar}$ 295 provides further confirmation of surface species desorption at $47{ }^{\circ} \mathrm{C}$ for as-received Ru/C (Fig. S6). 296 Therefore, as-received $\mathrm{Ru} / \mathrm{C}$ consists of highly reducible $\mathrm{Ru}$ oxides that are covered by surface 297 contaminants. The ex situ pretreatment of $\mathrm{Ru} / \mathrm{C}$ increased catalyst activity mainly by removing these 298 surface contaminants while causing minimal effect on Ru oxides particles.

299 The as-received $\mathrm{Ru} / \mathrm{Al}_{2} \mathrm{O}_{3}$ and ex situ $\mathrm{N}_{2}$ pretreated $\mathrm{Ru} / \mathrm{Al}_{2} \mathrm{O}_{3}$ exhibit a TPR pattern consistent with $300 \mathrm{RuO}_{2}$ reduction reported in the literature, which is also in agreement with the crystalline $\mathrm{RuO}_{2}$ identified 301 by XRD analysis. Although the stoichiometry for $\mathrm{H}_{2}$ consumption of $\mathrm{RuO}_{2}$ in these two $\mathrm{Ru} / \mathrm{Al}_{2} \mathrm{O}_{3}$ 302 catalysts is similar to that of $\mathrm{RuO}_{2}$ in ex situ $\mathrm{H}_{2}$ - and $\mathrm{N}_{2}$-pretreated $\mathrm{Ru} / \mathrm{C}$ (Table S2), the $\mathrm{Ru}$ oxides on 303 the two supports show significant differences in reducibility as evidenced by the much lower reduction 304 peak temperature of $\mathrm{Ru} / \mathrm{C}$ catalysts. Besides, the surface of $\mathrm{RuO}_{2}$ in ex situ $\mathrm{H}_{2}$ - and $\mathrm{N}_{2}$-pretreated $\mathrm{Ru} / \mathrm{C}$ 305 is easily reduced by $\mathrm{H}_{2}$ at $25{ }^{\circ} \mathrm{C}$, while the surface of $\mathrm{RuO}_{2}$ in as-received $\mathrm{Ru}^{\prime} / \mathrm{Al}_{2} \mathrm{O}_{3}$ and ex situ $\mathrm{N}_{2}$ 306 pretreated $\mathrm{Ru} / \mathrm{Al}_{2} \mathrm{O}_{3}$ is not reducible with $\mathrm{H}_{2}$ at $25{ }^{\circ} \mathrm{C}$ (Table S2). In contrast, ex situ $\mathrm{H}_{2}$ pretreated $307 \mathrm{Ru} / \mathrm{Al}_{2} \mathrm{O}_{3}$ shows a small $\mathrm{H}_{2}$ consumption peak at $45^{\circ} \mathrm{C}$, similar to the highly reducible $\mathrm{RuO}_{2}$ in ex situ $308 \mathrm{H}_{2}$ - and $\mathrm{N}_{2}$-pretreated $\mathrm{Ru} / \mathrm{C}$ and consistent with crystalline metallic $\mathrm{Ru}$ in ex situ $\mathrm{H}_{2}$ pretreated $\mathrm{Ru} / \mathrm{Al}_{2} \mathrm{O}_{3}$ 309 identified by XRD analysis. Based on these observations, it can be concluded that ex situ $\mathrm{H}_{2}$ 310 pretreatment activates $\mathrm{Ru} / \mathrm{Al}_{2} \mathrm{O}_{3}$ by reducing the crystalline $\mathrm{RuO}_{2}$ to a metallic Ru phase, whose surface 311 is re-oxidized upon exposure to ambient temperature air to a more redox-labile form of $\mathrm{RuO}_{2}$ (e.g., less 312 crystalline) that can be re-reduced by $\mathrm{H}_{2}$ at $25^{\circ} \mathrm{C}$. A complete re-oxidation of pretreated $\mathrm{Ru} / \mathrm{C}$ compared 
313 with partial re-oxidation of $\mathrm{H}_{2}$ pretreated $\mathrm{Ru} / \mathrm{Al}_{2} \mathrm{O}_{3}$ is attributed to a much smaller size of $\mathrm{Ru}$

314 nanoparticles in $\mathrm{Ru} / \mathrm{C}$ than in $\mathrm{Ru} / \mathrm{Al}_{2} \mathrm{O}_{3}$. The ex situ $\mathrm{N}_{2}$ pretreatment fails to activate $\mathrm{Ru} / \mathrm{Al}_{2} \mathrm{O}_{3}$ due to the

315 inability of $\mathrm{N}_{2}$ to transform crystalline $\mathrm{RuO}_{2}$ to redox-labile species. Therefore, it is further confirmed

316 that redox-labile surface $\mathrm{Ru}$ oxides are essential to achieve good performance in catalytic nitrate

317 reduction applications.

\section{3.3. Catalytic nitrite reduction}

319 Based on the prevailing mechanism for nitrate reduction with Pd-based catalysts, the first reduction 320 intermediate is anticipated to be nitrite $[32,82,83]$, and the fact that no nitrite intermediate is observed 321 when monitoring nitrate reactions (Fig. 2a) would suggest nitrite reduction is much faster than nitrate 322 reduction at comparable conditions (similar to observations reported for $\mathrm{Pd}$ catalysts under most 323 conditions [31, 74, 84]). Compared to nitrate, reduction of nitrite is less well described by a 324 pseudo-first-order rate law, with the reaction appearing to accelerate as nitrite concentration continues to 325 drop after the first two half-lives (Fig. 7a). Nevertheless, the pseudo-first-order rate constants for nitrite 326 reduction over the first two half-lives was calculated to provide a rough measure of catalyst activity to 327 compare with that measured for nitrate reduction under similar conditions. Surprisingly, the observed 328 reaction kinetics for nitrite are markedly slower than for nitrate under the same conditions. The 329 mass-normalized pseudo-first-order rate constant for nitrite reduction derived from the model fit of data 330 in Fig. $7 \mathrm{a}$ is $1.44 \pm 0.15 \mathrm{~L} \cdot \mathrm{g}_{\mathrm{Ru}}{ }^{-1} \cdot \mathrm{min}^{-1}$, corresponding to an $\mathrm{TOF}_{0}$ of $0.73 \pm 0.06 \mathrm{~min}^{-1}$. This value is

331 about one third of the $\mathrm{TOF}_{0}$ for nitrate measured under the same conditions $\left(2.1 \pm 0.2 \mathrm{~min}^{-1}\right)$. The lower 
332 activity of nitrite in comparison to nitrate contrasts with typical results reported for Pd-based bimetallic

333 catalysts, where nitrite is much more reactive than the parent nitrate ion $[39,74]$. Nitrite reaction with

$334 \mathrm{Pd} / \mathrm{C}$ at the same conditions shown in Fig. 7a yields a $\mathrm{TOF}_{0}$ of $57.7 \pm 9.2 \mathrm{~min}^{-1}$.

335 The isotope labeling mass balance closure experiment conducted with nitrite as a starting reactant (Fig.

336 2b) further reveals a distinct behavior of Ru-catalyzed nitrite reduction. In contrast to the experiment

337 initiated with nitrate, nitrite reduction yields a mixture of $\mathrm{N}_{2}$ and ammonium endproducts, and $\mathrm{N}_{2} \mathrm{O}$ is

338 observed as a reaction intermediate. Whereas the sole product of nitrate reduction detected is ammonium

339 irrespective of initial nitrate concentration (Fig. 8a), the distribution of $\mathrm{N}_{2}$ :ammonium observed in nitrite

340 reduction experiments shifts increasingly towards $\mathrm{N}_{2}$ with increasing initial nitrite concentration (Fig.

$3418 b)$.

342 3.4. Site-limited reduction kinetics

343 As mentioned earlier, measured nitrite concentrations drop below pseudo-first-order kinetic model

344 predictions as the reaction progresses and nitrite concentration decreases (Fig. 7a). To examine this

345 further, $\mathrm{TOF}_{0}$ of nitrate and nitrite reduction were determined at varying initial concentration of each

346 oxyanion. Results of these measurements (Fig. 7b) reveal contrasting behavior for nitrate and nitrite. For

347 nitrate, the observed trend is consistent with the classical Langmuir-Hinshelwood model for

348 heterogeneous reactions, where $\mathrm{TOF}_{0}$ increases with increasing initial nitrate concentration until it

349 approaches a maximum value due to saturation of available surface reaction sites [86]. Similar behavior

350 has been documented for many heterogeneous catalytic reactions, including nitrate, nitrite, and bromate 
351 reactions with $\mathrm{Pd}$-based catalyst $[33,87,88]$. The small drop in $\mathrm{TOF}_{0}$ observed at the highest initial 352 nitrate concentration tested may result from competitive adsorption between nitrate and $\mathrm{H}_{2}$ on the same 353 reaction sites [89]. A contrasting and atypical behavior is observed for nitrite, where $\mathrm{TOF}_{0}$ values are 354 greatest at the lowest initial nitrite concentration and decrease to minimum value with increasing nitrite 355 concentration. To rationalize this trend within the framework of a Langmuir-Hinshelwood model 356 requires an assumption that nitrite competes directly with $\mathrm{H}_{2}$ for the same reaction sites and the former 357 has a much higher affinity for the sites than the latter, thereby inhibiting uptake and dissociation of the 358 required $\mathrm{H}_{2}$ reductant at higher nitrite concentrations. An important implication of this finding is that the 359 relative reactivities observed for nitrate versus nitrite (e.g., Fig. 7a) are heavily dependent upon the 360 initial oxyanion concentrations used in the reactions. The heightened reactivity of nitrite at low nitrite 361 concentrations can also potentially explain why the species is not observed as a reaction intermediate 362 during $\mathrm{Ru}$ catalyst reactions initiated with nitrate; when nitrite is formed at low concentrations on the 363 catalyst surface, its rapid turnover under these conditions prevents detection in the overlying aqueous 364 solution. The competition between nitrite and $\mathrm{H}_{2}$ adsorption may also contribute to the observed shift in 365 endproduct selectivity towards ammonium at lower initial nitrite concentration (Fig. 8b); conversion of 366 nitrite to ammonium has a relatively higher stoichiometric requirement for $\mathrm{H}_{2}$ than reduction to $\mathrm{N}_{2}$, so 367 an increase in $\mathrm{H}_{2}$ :nitrite ratio could favor the pathway for ammonium production by increasing surface 368 coverage of hydrogen and decreasing surface coverage of nitrogen species. The decreasing nitrite 
concentration is also expected to reduce the rate of $\mathrm{N}-\mathrm{N}$ pairing reactions necessary to $\mathrm{N}_{2} \mathrm{O}$ and $\mathrm{N}_{2}$.

370 Detailed pathways will be discussed in the following section.

371 Since separate reactions conducted with nitrate and nitrate suggest that the oxyanions both compete 372 with $\mathrm{H}_{2}$ for chemisorption at $\mathrm{Ru}$ active sites, competitive reactions between the two oxyanions were 373 further examined by reaction initiated with mixtures of nitrate and nitrite. Fig. 7c shows the reaction of 374 an equimolar mixture of nitrate and nitrite at the same conditions as the individual oxyanion reactions 375 shown in Fig. 7a. Interestingly, despite the fact that nitrite reacts slower than nitrate when the two 376 oxyanions are reacted with $\mathrm{Ru} / \mathrm{C}$ separately, the presence of nitrite severely inhibits nitrate reduction.

377 Nitrate reduction kinetics proceeds in two phases. A severely inhibited reduction phase is observed 378 while nitrite is present, but the reaction accelerates once the nitrite is fully depleted. Variation of the 379 ratio of initial nitrate and nitrite confirmed competition between the two oxyanions for available 380 catalysts reaction sites, since the initial rate of nitrate reduction in the first phase increases with 381 increasing nitrate/nitrite ratio, which is the same case for nitrite reduction measured in the presence of 382 nitrate (Table S3).

\section{3.5. Proposed reaction pathway}

$384 \mathrm{Ru}$ catalysts behave differently from Pd-based catalysts in nitrate reduction product selectivity. For 385 example, Ru catalysts favor complete selectivity for ammonium (Fig. 2a), in contrast with a mixture of 386 ammonium and $\mathrm{N}_{2}$ endproducts reported for Pd-based bimetallic catalysts [23, 31]. Consistently high 387 (and possibly complete) selectivity for ammonium was observed for Ru catalysts under various solution 
$388 \mathrm{pH}$, whereas the ratio between ammonium and $\mathrm{N}_{2}$ varies with shifting $\mathrm{pH}$ conditions for Pd-based

389 bimetallic catalysts $[31,41,72]$. On the other hand, $\mathrm{Ru}$ catalysts and Pd-based catalysts share similarity

390 in nitrite reduction product selectivity. For $\mathrm{Ru} / \mathrm{C}$, the distribution of $\mathrm{N}_{2}$ :ammonium shifts increasingly

391 towards $\mathrm{N}_{2}$ with increasing initial nitrite concentration (Fig. 8b), similar to trends reported for Pd-based

392 catalysts [85]. Scheme 1 depicts the generally accepted mechanism of nitrate reduction on Pd-based

393 catalysts. The experimental observations of nitrite reduction with $\mathrm{Ru}$ catalysts appear to be consistent

394 with the reaction pathways proposed for Pd-based catalysts. Reactions initiated with nitrite yield

395 transient intermediates and endproducts consistent with the two parallel pathways for NO reduction (Fig.

396 2b). It may not be straightforward to apply the scheme to nitrate reduction with Ru catalysts considering

397 the differences mentioned above and that reactions initiated with nitrate show no detectable nitrite

398 intermediate (Fig. 2a). However, the lack of observed nitrite intermediate is consistent with the elevated

399 turnover rate of this species observed at low initial concentrations (Fig. 7b) and selective reactivity of

400 nitrite in the presence of nitrate (Fig. 7c). Along this line, the complete selectivity for ammonium is

401 possibly a result of high selectivity to ammonium at low nitrite concentration (Fig. 8b).

402 It should be pointed out that Scheme 1 only provides a macroscopic picture for the reaction. When

403 considering the reaction from the microscopic viewpoint, the mechanism involves much more diverse

404 intermediates that are adsorbed on the surface or in the aqueous phase. To obtain molecular insights into

405 the mechanism of the reaction over $\mathrm{Ru}$, DFT calculations were conducted to evaluate the

406 thermodynamics of adsorption and transformation steps. Adsorption energies and conformations of 
407 major reactants, hypothesized intermediates and products are provided in SI Table S4. The elementary 408 steps underlying the reaction pathways in Scheme 1 are illustrated in Fig. 9, and the energetics of each 409 step are listed in Table $\mathrm{S} 5$. The strong adsorption of $\mathrm{NO}_{2}^{-}(-1.3 \mathrm{eV})$ and $\mathrm{NO}(-2.0 \mathrm{eV})$ from water to the $410 \mathrm{Ru}$ cluster surface may be contributing to the fact that desorbed aqueous species of the latter two were 411 never observed during reactions initiated with nitrate. The further sequential reduction of $\mathrm{NO}_{a d s}$ to $412 \mathrm{NH}_{3, a d s}$ occurs through a series of exothermic reaction steps. Previous observations of the complete 413 selectivity for ammonium in reactions initiated with nitrate (Fig. 8a) and the shift in endproduct 414 selectivity towards $\mathrm{N}_{2}$ for nitrite reactions conducted with higher initial aqueous concentrations (Fig. 8b) 415 indicate that buildup of aqueous nitrite concentrations is a prerequisite for the reaction pathway leading 416 to diatomic nitrogen species. We found that initiating $\mathrm{N}-\mathrm{N}$ coupling by reaction of the $\mathrm{NO}_{a d s}$ 417 intermediate with aqueous nitrite is exothermic, and subsequent reduction of the resulting intermediate 418 to form both the detectable $\mathrm{N}_{2} \mathrm{O}$ intermediate and stable $\mathrm{N}_{2}$ endproduct are also favorable. Some have 419 proposed that $\mathrm{NO}_{a d s}$ dissociates first to $\mathrm{N}_{a d s}$ and $\mathrm{O}_{a d s}$ on catalyst metal surfaces before reacting further to 420 form the observed products $[30,85]$. DFT calculations indicate that this route cannot be ruled out based 421 on energetics, but coupling between $\mathrm{N}_{\mathrm{ads}}$ and $\mathrm{NO}_{\mathrm{ads}}$ is unfavorable. The findings from DFT calculations 422 that both reaction pathways are thermodynamically favorable implies that the kinetic factors, rather than 423 thermodynamic constraints, are likely responsible for controlling the reaction product selectivity. 424 Calculations of kinetic properties will be needed to provide further insights into the reaction rates and 425 endproduct selectivities observed in experiments. 


\subsection{Implications for technology development}

427 Results of this study demonstrate that Ru catalysts effectively reduce nitrate at ambient temperature 428 and $\mathrm{H}_{2}$ pressure. Ru possesses many of the benefits of other Pt group metal catalysts (e.g., high stability) 429 but is less expensive than $\mathrm{Pd}$ and $\mathrm{Pt}$, showing potential to reduce barriers to catalyst technology adoption 430 for treatment of recalcitrant water contaminants. The reductant $\left(\mathrm{H}_{2}\right)$ is low cost, can be generated on-site 431 electrochemically, and has lower life-cycle environmental impacts than organic electron donors typically 432 used in biological denitrification processes [24]. The catalysts used in the study are a commercially 433 available material from a vendor capable to high volume production, making the process accessible to 434 near-term commercial applications. The sole endproduct from nitrate reduction by the supported $\mathrm{Ru}$ 435 catalysts investigated was ammonium, indicating that $\mathrm{Ru}$ catalysts are not suitable for treating drinking 436 water with dilute nitrate in a single process. On the other hand, highly selective conversion of nitrate to 437 ammonium, especially in concentrate matrices like waste ion exchange regenerant brines [90], if 438 followed by separation unit processes (e.g., membrane electrolysis [91]), may be a promising strategy 439 for sustainably recovering an economically valuable product (e.g., $\left.\left(\mathrm{NH}_{4}\right)_{2} \mathrm{SO}_{4}\right)$, which is in line with a 440 growing interest in resource recovery from waste streams [92]. A number of technology development 441 challenges remain to demonstrate viability, safety, and to de-risk the technology, but findings in this 442 study suggest a path forward for development of an economical and sustainable technology for treatment 443 and resource recovery from nitrate-contaminated water sources. 
444 Rational design that emphasizes "design-for-purpose" is important to advance next-generation water 445 treatment technologies [93]. Pt group metals are known to activate $\mathrm{H}_{2}$. In order to couple $\mathrm{H}_{2}$ oxidation 446 with nitrate reduction, the activity of nitrate activation on $\mathrm{Ru}$ and the steps controlling selectivity need to 447 be understood and is the objective of this study. Examination of the reaction mechanism revealed that 448 selectivity for $\mathrm{N}_{2}$ endproduct is limited during nitrate reduction with the $\mathrm{Ru}$ catalyst formulations 449 examined here because N-N coupling requires significant aqueous nitrite concentrations to buildup and 450 pairing between adsorbed $\mathrm{N}$ species is negligible. This suggests a target for future $\mathrm{Ru}$ catalyst design: 451 tailor active sites for selective adsorption with nitrate over nitrite and/or reducing barriers to mobility 452 and pairing of adsorbed $\mathrm{N}$ species. Surface alloying may be used to alter small molecule binding 453 strength and rates of surface species diffusion [94, 95]. Alternatively, bio-inspired catalyst structures that 454 attempt to mimic the multi-component features and activated metalloenzyme centers of biological 455 systems may offer a promising strategy for enhancing catalyst activity. For example, Liu and co-workers 456 recently demonstrated $>100$-fold improvement in catalytic reduction of the recalcitrant oxyanion 457 perchlorate by modifying the Re component within $\mathrm{Pd}-\mathrm{Re} / \mathrm{C}$ bimetallic catalysts by complexing with 458 oxazoline ligands that enhance the metal's oxygen atom transfer (OAT) reactivity [96], mimicking the 459 design of Mo-centered OAT metal complexes in the perchlorate reductase enzyme. Inspired by the 460 heme-containing active sites of nitrate and (per)chlorate reductase, Ford and co-workers constructed a 461 non-heme iron complex for catalytic nitrate and perchlorate reduction, and the homogeneous catalyst is 
462 regenerated by electrons and protons provided by 1,2-diphenylhydrazine [97]. Biomimetic catalysts

463 incorporating $\mathrm{Ru}$ as the active metal center for nitrate or nitrite reduction have not been reported to date.

\section{4. Conclusions}

465 Supported $\mathrm{Ru}$ nanoparticles showed promising catalytic performance in reducing nitrate in water at

466 ambient temperature and $\mathrm{H}_{2}$ pressure. It is demonstrated that $\mathrm{Ru}$ has a high intrinsic activity in nitrate

467 activation, which is five times higher than that of $\mathrm{Pd}$ under standard testing conditions. The key features

468 for supported $\mathrm{Ru}$ catalysts that need to be controlled to achieve high activity are that reduced Ru surface

469 can be obtained by $\mathrm{H}_{2}$ reduction at reaction temperature and that the surface is not blocked by synthesis

470 residues. $\mathrm{Ru}$ reduces nitrate selectively to ammonium, while nitrite is reduced to yield a mixture of $\mathrm{N}_{2}$

471 and ammonium, with selectivity shifting towards $\mathrm{N}_{2}$ at increasing nitrite:hydrogen ratio. The reaction

472 mechanism is proposed that sequential hydrogenation of nitrate to nitrite and NO is followed by parallel

473 pathways involving the adsorbed NO: (1) sequential hydrogenation to ammonium, and (2) N-N coupling

474 with aqueous nitrite followed by hydrogenation to the detected $\mathrm{N}_{2} \mathrm{O}$ intermediate and $\mathrm{N}_{2}$ endproduct.

475 Future work is needed to strategically design catalyst to control selectivity and develop integrated

476 processes for nitrogen recovery.

477 Acknowledgements

478 This work was supported by the National Science Foundation (CBET-1555549) and the U.S. EPA

479 Science to Achieve Results Program (\#RD83517401). Computational resources from High Performance

480 Computing facility at CSM are gratefully acknowledged. We thank Ryan Richards, Martin Menart and 
481 Mengze $\mathrm{Xu}$ (CSM) for access and assistance with gas adsorption measurements. We thank David

482 Diercks (CSM) for assistance with STEM analysis. Charles Werth (Univ. Texas), Danmeng Shuai

483 (George Washington Univ.) and Yun Shen (Univ. of Illinois) are also acknowledged for their advice and

484 helpful discussions.

485

486 References

487 [1] R.F. Spalding, M.E. Exner, J. Environ. Qual., 22 (1993) 392-402.

488 [2] A. Kapoor, T. Viraraghavan, J. Environ. Eng.-ASCE, 123 (1997) 371-380.

489 [3] L.J. Puckett, Environ. Sci. Technol., 29 (1995) 408A-414A.

490 [4] A. Pintar, Catal. Today, 77 (2003) 451-465.

491 [5] P.J. Weyer, J.R. Cerhan, B.C. Kross, G.R. Hallberg, J. Kantamneni, G. Breuer, M.P. Jones, W. 492 Zheng, C.F. Lynch, Epidemiology, 12 (2001) 327-338.

493 [6] G. Gulis, M. Czompolyova, J.R. Cerhan, Environ. Res., 88 (2002) 182-187.

494 [7] J.K. Choe, A.M. Bergquist, S. Jeong, J.S. Guest, C.J. Werth, T.J. Strathmann, Water Res., 80 (2015) 495 267-280.

496 [8] S. Samatya, N. Kabay, U. Yuksel, M. Arda, M. Yuksel, React. Funct. Polym., 66 (2006) 1206-1214.

497 [9] J. Bohdziewicz, M. Bodzek, E. Wasik, Desalination, 121 (1999) 139-147.

498 [10] A. El Midaoui, F. Elhannouni, M. Taky, L. Chay, M.A.M. Sahli, L. Echihabi, M. Hafsi, Sep. Purif. 499 Technol., 29 (2002) 235-244.

500 [11] F. Hell, J. Lahnsteiner, H. Frischherz, G. Baumgartner, Desalination, 117 (1998) 173-180.

501 [12] B.-U. Bae, Y.-H. Jung, W.-W. Han, H.-S. Shin, Water Res., 36 (2002) 3330-3340.

502 [13] N. Barrabés, J. Sá, Appl. Catal., B, 104 (2011) 1-5.

503 [14] M. Shrimali, K.P. Singh, Environ. Pollut., 112 (2001) 351-359.

504 [15] I. Mikami, Y. Yoshinaga, T. Okuhara, Appl. Catal., B, 49 (2004) 173-179.

505 [16] C.-P. Huang, H.-W. Wang, P.-C. Chiu, Water Res., 32 (1998) 2257-2264.

506 [17] A.P. Murphy, Nature, 350 (1991) 223-225.

507 [18] M. Kumar, S. Chakraborty, J. Hazard. Mater., 135 (2006) 112-121.

508 [19] F. Gauthard, F. Epron, J. Barbier, J. Catal., 220 (2003) 182-191.

509 [20] B.P. Chaplin, E. Roundy, K.A. Guy, J.R. Shapley, C.J. Werth, Environ. Sci. Technol., 40 (2006) $510 \quad 3075-3081$.

511 [21] I. Dodouche, D.P. Barbosa, M.d.C. Rangel, F. Epron, Appl. Catal., B, 93 (2009) 50-55.

512 [22] R. Zhang, D.M. Shuai, K.A. Guy, J.R. Shapley, T.J. Strathmann, C.J. Werth, ChemCatChem, 5 513 (2013) 313-321. 
514 [23] S. Jung, S. Bae, W. Lee, Environ. Sci. Technol., 48 (2014) 9651-9658.

515 [24] J.K. Choe, M.H. Mehnert, J.S. Guest, T.J. Strathmann, C.J. Werth, Environ. Sci. Technol., 47 516 (2013) 4644-4652.

517 [25] U. Prüsse, K.-D. Vorlop, J. Mol. Catal. A: Chem., 173 (2001) 313-328.

518 [26] J. Jung, S. Bae, W. Lee, Appl. Catal., B, 127 (2012) 148-158.

519 [27] S. Hörold, T. Tacke, K.D. Vorlop, Environ. Technol., 14 (1993) 931-939.

520 [28] O. Soares, J.J.M. Orfao, M.F.R. Pereira, Catal. Lett., 126 (2008) 253-260.

521 [29] D. Shuai, J.K. Choe, J.R. Shapley, C.J. Werth, Environ. Sci. Technol., 46 (2012) 2847-2855.

522 [30] O.M. Ilinitch, L.V. Nosova, V.V. Gorodetskii, V.P. Ivanov, S.N. Trukhan, E.N. Gribov, S.V. 523 Bogdanov, F.P. Cuperus, J. Mol. Catal. A: Chem., 158 (2000) 237-249.

524 [31] Y. Yoshinaga, T. Akita, I. Mikami, T. Okuhara, J. Catal., 207 (2002) 37-45.

525 [32] U. Prüsse, M. Hähnlein, J. Daum, K.-D. Vorlop, Catal. Today, 55 (2000) 79-90.

526 [33] A. Pintar, J. Batista, J. Levec, T. Kajiuchi, Appl. Catal., B, 11 (1996) 81-98.

527 [34] A. Pintar, J. Batista, I. Arčon, A. Kodre, Characterization of $\gamma$-Al2O3 supported Pd-Cu bimetallic 528 catalysts by EXAFS, AES and kinetic measurements, in: B. Delmon, P.A. Jacobs, R. Maggi, J.A. 529 Martens, P. Grange, G. Poncelet (Eds.) Stud. Surf. Sci. Catal., Elsevier, Louvain-la-Neuve, Belgium, 530 1998, pp. 127-136.

531 [35] F.A. Marchesini, S. Irusta, C. Querini, E. Miró, Appl. Catal., A, 348 (2008) 60-70.

532 [36] A. Miyazaki, K. Matsuda, F. Papa, M. Scurtu, C. Negrila, G. Dobrescu, I. Balint, Catal. Sci. 533 Technol., 5 (2015) 492-503.

534 [37] S. Bae, J. Jung, W. Lee, Chem. Eng. J., 232 (2013) 327-337.

535 [38] S. Hörold, K.D. Vorlop, T. Tacke, M. Sell, Catal. Today, 17 (1993) 21-30.

536 [39] K.A. Guy, H. Xu, J.C. Yang, C.J. Werth, J.R. Shapley, J. Phys. Chem. C, 113 (2009) 8177-8185.

537 [40] X. Fan, C. Franch, E. Palomares, A.A. Lapkin, Chem. Eng. J., 175 (2011) 458-467.

538 [41] G. Centi, S. Perathoner, Appl. Catal., B, 41 (2003) 15-29.

539 [42] F.X. Zhang, S. Miao, Y.L. Yang, X. Zhang, J.X. Chen, N.J. Guan, J. Phys. Chem. C, 112 (2008)

$540 \quad 7665-7671$.

541 [43] Z. Xu, L. Chen, Y. Shao, D. Yin, S. Zheng, Ind. Eng. Chem. Res., 48 (2009) 8356-8363.

542 [44] M. D’Arino, F. Pinna, G. Strukul, Appl. Catal., B, 53 (2004) 161-168.

543 [45] H.Y. Chen, S.L. Lo, H.H. Ou, Appl. Catal., B, 142 (2013) 65-71.

544 [46] F. Epron, F. Gauthard, C. Pinéda, J. Barbier, J. Catal., 198 (2001) 309-318.

545 [47] http://www.platinum.matthey.com/prices/price-charts. (accessed 01/07, 2017)

546 [48] R. Brunet Espinosa, L. Lefferts, ACS Catal., 6 (2016) 5432-5440.

547 [49] http://www.infomine.com/investment/metal-prices/nickel/. (accessed 01/07, 2017)

548 [50] L. Calvo, M.A. Gilarranz, J.A. Casas, A.F. Mohedano, J.J. Rodriguez, Ind. Eng. Chem. Res., 49 549 (2010) 5603-5609.

550 [51] B.P. Chaplin, M. Reinhard, W.F. Schneider, C. Schuth, J.R. Shapley, T.J. Strathmann, C.J. Werth, 551 Environ. Sci. Technol., 46 (2012) 3655-3670. 
[52] J. Petró, A. Bóta, K. László, H. Beyer, E. Kálmán, I. Dódony, Appl. Catal., A, 190 (2000) 73-86. [53] L. Chen, Y. Zhu, H. Zheng, C. Zhang, B. Zhang, Y. Li, J. Mol. Catal. A: Chem., 351 (2011) 217-227.

[54] T. Yoneda, T. Takido, K. Konuma, Appl. Catal., B, 84 (2008) 667-677.

[55] G.E. Dima, A.C.A. de Vooys, M.T.M. Koper, J. Electroanal. Chem., 554-555 (2003) 15-23.

[56] X. Chen, X. Huo, J. Liu, Y. Wang, C.J. Werth, T.J. Strathmann, Chem. Eng. J., 313 (2017) 745-752.

[57] L. Lemaignen, C. Tong, V. Begon, R. Burch, D. Chadwick, Catal. Today, 75 (2002) 43-48.

[58] S.-F. Yin, Q.-H. Zhang, B.-Q. Xu, W.-X. Zhu, C.-F. Ng, C.-T. Au, J. Catal., 224 (2004) 384-396.

[59] F.R. García-García, A. Guerrero-Ruiz, I. Rodríguez-Ramos, Top. Catal., 52 (2009) 758-764.

[60] R. Sander, Compilation of Henry's Law Constants for Inorganic and Organic Species of Potential Importance in Environmental Chemistry. http://www.henrys-law.org (accessed July 2016).

[61] Gaussian 09, Revision C.01, M.J. Frisch, G.W. Trucks, H.B. Schlegel, G.E. Scuseria, M.A. Robb, J.R. Cheeseman, G. Scalmani, V. Barone, B. Mennucci, G.A. Petersson, H. Nakatsuji, M. Caricato, X. Li, H.P. Hratchian, A.F. Izmaylov, J. Bloino, G. Zheng, J.L. Sonnenberg, M. Hada, M. Ehara, K. Toyota, R. Fukuda, J. Hasegawa, M. Ishida, T. Nakajima, Y. Honda, O. Kitao, H. Nakai, T. Vreven, J.A.

Montgomery Jr, J.E. Peralta, F. Ogliaro, M.J. Bearpark, J. Heyd, E.N. Brothers, K.N. Kudin, V.N. Staroverov, R. Kobayashi, J. Normand, K. Raghavachari, A.P. Rendell, J.C. Burant, S.S. Iyengar, J. Jaramillo, R. Gomperts, R.E. Stratmann, O. Yazyev, A.J. Austin, R. Cammi, C. Pomelli, J.W. Ochterski, R.L. Martin, K. Morokuma, V.G. Zakrzewski, G.A. Voth, P. Salvador, J.J. Dannenberg, S. Dapprich, CT, USA, 2009.

[62] F. Aguilera-Granja, L.C. Balbás, A. Vega, J. Phys. Chem. A, 113 (2009) 13483-13491.

[64] C. Adamo, V. Barone, J. Chem. Phys., 110 (1999) 6158-6170.

[65] H.T. Dunning, Jr., P.J. Hay, Gaussian basis sets for molecular calculations, in: Schaefer, H. F. (Ed.), Methods of Electronic Structure Theory, Springer: New York, 1977, pp. 1-27.

[66] P.J. Hay, W.R. Wadt, J. Chem. Phys., 82 (1985) 299-310.

[68] M.M. Quintal, A. Karton, M.A. Iron, A.D. Boese, J.M.L. Martin, J. Phys. Chem. A, 110 (2006) 709-716.

[69] P. Janthon, S. Luo, S.M. Kozlov, F. Viñes, J. Limtrakul, D.G. Truhlar, F. Illas, J. Chem. Theory. Comput., 10 (2014) 3832-3839.

[70] J. Tomasi, B. Mennucci, E. Cancès, J. Mol. Struc.-THEOCHEM, 464 (1999) 211-226.

[71] J. Trawczyński, P. Gheek, J. Okal, M. Zawadzki, M.J.I. Gomez, Appl. Catal., A, 409-410 (2011) 39-47.

[72] B. Chaplin, J. Shapley, C. Werth, Catal. Lett., 130 (2009) 56-62. 
591 http://www.micromeritics.com/repository/files/autochem_ii_2920_operator_manual_v4.00.pdf.

592 [74] F. Deganello, L.F. Liotta, A. Macaluso, A.M. Venezia, G. Deganello, Appl. Catal., B, 24 (2000) $593 \quad 265-273$.

594 [75] A. Garron, F. Epron, Water Res., 39 (2005) 3073-3081.

595 [76] J. Sá, H. Vinek, Appl. Catal., B, 57 (2005) 247-256.

596 [77] M.P. Maia, M.A. Rodrigues, F.B. Passos, Catal. Today, 123 (2007) 171-176.

597 [78] D. Shuai, D.C. McCalman, J.K. Choe, J.R. Shapley, W.F. Schneider, C.J. Werth, ACS Catal., 3 598 (2013) 453-463.

599 [79] S. Hosokawa, H. Kanai, K. Utani, Y.-i. Taniguchi, Y. Saito, S. Imamura, Appl. Catal., B, 45 (2003) $600 \quad 181-187$.

601 [80] W. Deng, X. Tan, W. Fang, Q. Zhang, Y. Wang, Catal. Lett., 133 (2009) 167-174.

602 [81] S. Kundu, Y. Wang, W. Xia, M. Muhler, J. Phys. Chem. C, 112 (2008) 16869-16878.

603 [82] F. Epron, F. Gauthard, J. Barbier, J. Catal., 206 (2002) 363-367.

604 [83] A.O. Costa, L.S. Ferreira, F.B. Passos, M.P. Maia, F.C. Peixoto, Appl. Catal., A, 445-446 (2012) $605 \quad 26-34$.

606 [84] S. Hamid, M.A. Kumar, W. Lee, Appl. Catal., B, 187 (2016) 37-46.

607 [85] H. Shin, S. Jung, S. Bae, W. Lee, H. Kim, Environ. Sci. Technol., 48 (2014) 12768-12774.

608 [86] M.A. Vannice, Kinetics of Catalytic Reactions, Springer, New York, 2005.

609 [87] J.K. Chinthaginjala, L. Lefferts, Appl. Catal., B, 101 (2010) 144-149.

610 [88] H. Chen, Z. Xu, H. Wan, J. Zheng, D. Yin, S. Zheng, Appl. Catal., B, 96 (2010) 307-313.

611 [89] L.E. Knitt, J.R. Shapley, T.J. Strathmann, Environ. Sci. Technol., 42 (2008) 577-583.

612 [90] A.M. Bergquist, J.K. Choe, T.J. Strathmann, C.J. Werth, Water Res., 96 (2016) 177-187.

613 [91] J. Desloover, A. Abate Woldeyohannis, W. Verstraete, N. Boon, K. Rabaey, Environ. Sci. Technol., 61446 (2012) 12209-12216.

615 [92] P. Kuntke, K.M. Śmiech, H. Bruning, G. Zeeman, M. Saakes, T.H.J.A. Sleutels, H.V.M. Hamelers, 616 C.J.N. Buisman, Water Res., 46 (2012) 2627-2636.

617 [93] R. Li, L. Zhang, P. Wang, Nanoscale, 7 (2015) 17167-17194.

618 [94] S. St. John, R.W. Atkinson, R.R. Unocic, T.A. Zawodzinski, A.B. Papandrew, J. Phys. Chem. C, 619119 (2015) 13481-13487.

620 [95] A.U. Nilekar, J. Greeley, M. Mavrikakis, Angew. Chem. Int. Ed., 45 (2006) 7046-7049.

621 [96] J. Liu, J.K. Choe, Y. Wang, J.R. Shapley, C.J. Werth, T.J. Strathmann, ACS Catal., (2014) $622 \quad 511-522$.

623 [97] C.L. Ford, Y.J. Park, E.M. Matson, Z. Gordon, A.R. Fout, Science, 354 (2016) 741-743. 
625 Scheme 1. Nitrate hydrogenation pathway on Pd-based bimetallic catalysts

Fig. 1. Measured reaction timecourses for nitrate reduction and first-order model fits on $5 \mathrm{wt} \% \mathrm{Ru} / \mathrm{C}, 5$ $\mathrm{wt} \% \mathrm{Pd} / \mathrm{C}$, and $5 \mathrm{wt} \% \mathrm{Pd}-1 \mathrm{wt} \% \mathrm{Cu} / \mathrm{C}$ in the semi-batch reactor system $\left(0.2 \mathrm{~g} \cdot \mathrm{L}^{-1}\right.$ catalyst, $\left[\mathrm{NO}_{3}{ }^{-}\right]_{0}=1.6$ $\mathrm{mM}, 1 \mathrm{~atm} \mathrm{H}_{2}$ continuous sparging except in control experiments where $1 \mathrm{~atm} \mathrm{~N}_{2}$ continuous sparging was used, $\mathrm{pH} 5.0$ maintained by $\mathrm{pH}$ stat, $25 \pm 0.5^{\circ} \mathrm{C}$ ). Error bars represent standard deviations of triplicate reactions.

\section{Table 1. Properties of catalysts used for nitrate activity test}

Fig. 2. Timecourses showing aqueous and gaseous intermediates and products during $\mathrm{Ru} / \mathrm{C}$-catalyzed reduction of ${ }^{15} \mathrm{~N}$-labeled (a) nitrate and (b) nitrite monitored in closed-bottle batch systems $\left(0.2 \mathrm{~g} \cdot \mathrm{L}^{-1}\right.$ catalyst, $\left[{ }^{15} \mathrm{NO}_{3}^{-}\right]_{0}$ or $\left[{ }^{15} \mathrm{NO}_{2}{ }^{-}\right]_{0}=1.6 \mathrm{mM}$, initially $1 \mathrm{~atm} \mathrm{H}_{2}, \mathrm{pH} 5.5$ buffered by $40 \mathrm{mM}$ MES, $21 \pm$ $1{ }^{\circ} \mathrm{C}$ ). Error bars represent standard deviations of triplicate reactions (smaller than symbol if not visible).

Fig. 3. HAADF-STEM images of (a) ex situ $\mathrm{H}_{2}$ pretreated $\mathrm{Ru} / \mathrm{C}$, (b) $\mathrm{Ru} / \mathrm{C}$ after re-use experiment, (c) as-received $\mathrm{Ru} / \mathrm{C}$ and (d) ex situ $\mathrm{H}_{2}$ pretreated $\mathrm{Ru} / \mathrm{Al}_{2} \mathrm{O}_{3}$. The insets show $\mathrm{Ru}$ particle size distributions.

Fig. 4. Influence of catalyst pretreatments (as-received catalyst or ex situ pretreated in flowing $\mathrm{H}_{2}$ or $\mathrm{N}_{2}$ at $350{ }^{\circ} \mathrm{C}$ for $\left.2 \mathrm{~h}\right)$ on reactivity with aqueous nitrate $\left(0.2 \mathrm{~g} \cdot \mathrm{L}^{-1}\right.$ catalyst with nominal $5 \mathrm{wt} \% \mathrm{Ru}$ or $\mathrm{Pd}$, $\left[\mathrm{NO}_{3}{ }^{-}\right]_{0}=1.6 \mathrm{mM}, 1$ atm $\mathrm{H}_{2}$ continuous sparging, $\mathrm{pH} 5.0$ maintained by automatic $\mathrm{pH}$ stat, $25 \pm 0.5^{\circ} \mathrm{C}$ ). Error bars represent standard deviations of triplicate reactions (smaller than symbol if not visible). $\mathrm{NR}=$ no reaction observed.

Fig. 5. XRD patterns of (a) $\mathrm{Ru} / \mathrm{C}$ and (b) $\mathrm{Ru} / \mathrm{Al}_{2} \mathrm{O}_{3}$ collected after different ex situ pretreatments. Peaks assigned to $\mathrm{Ru}$ metal (O) and $\mathrm{RuO}_{2}(*)$ are indicated.

Fig. 6. TPR profiles of (a) as-received $\mathrm{Ru} / \mathrm{C}$, (b) ex situ $\mathrm{N}_{2}$ pretreated $\mathrm{Ru} / \mathrm{C}$, (c) ex situ $\mathrm{H}_{2}$ pretreated $\mathrm{Ru} / \mathrm{C}$, (d) as-received $\mathrm{Ru} / \mathrm{Al}_{2} \mathrm{O}_{3}$, (e) ex situ $\mathrm{N}_{2}$ pretreated $\mathrm{Ru} / \mathrm{Al}_{2} \mathrm{O}_{3}$, and (f) ex situ $\mathrm{H}_{2}$ pretreated $\mathrm{Ru} / \mathrm{Al}_{2} \mathrm{O}_{3}$. TCD signals are normalized with sample mass.

Fig. 7. (a) Comparison of $\mathrm{Ru} / \mathrm{C}$-catalyzed nitrite reaction kinetics with nitrate reaction at standard conditions $\left(0.2 \mathrm{~g} \cdot \mathrm{L}^{-1} \mathrm{Ru} / \mathrm{C},\left[\mathrm{NO}_{3}\right]_{0}\right.$ or $\left.\left[\mathrm{NO}_{2}{ }^{-}\right]_{0}=1.6 \mathrm{mM}\right)$. (b) $\mathrm{TOF}_{0}$ of $\mathrm{Ru} / \mathrm{C}$-catalyzed nitrate and nitrite reduction as a function of initial concentration of the target oxyanion $\left(0.2 \mathrm{~g} \cdot \mathrm{L}^{-1} \mathrm{Ru} / \mathrm{C}\right)$. (c) Measured timecourses for the simultaneous reduction of nitrate and nitrite added to a suspension containing $\mathrm{Ru} / \mathrm{C}$ $\left(0.2 \mathrm{~g} \cdot \mathrm{L}^{-1}\right.$ catalyst, $\left.\left[\mathrm{NO}_{3}{ }^{-}\right]_{0}=\left[\mathrm{NO}_{2}{ }^{-}\right]_{0}=1.6 \mathrm{mM}\right)$. Other conditions include $1 \mathrm{~atm} \mathrm{H}_{2}$ continuous sparging, $\mathrm{pH} 5.0$ maintained by automatic $\mathrm{pH}$ stat, and $25 \pm 0.5^{\circ} \mathrm{C}$. Error bars in panels a-b represent standard deviations of triplicate reactions. 
664 Fig. 8. Effect of initial (a) nitrate and (b) nitrite concentration on $\mathrm{NH}_{4}{ }^{+} / \mathrm{N}_{2}$ product selectivity (yellow: $665 \mathrm{NH}_{4}^{+}$; blue: $\mathrm{N}_{2}$ ). Product selectivity is based on percent molar $\mathrm{N}$ concentration. Error bars represent 666 standard deviations of triplicate reactions (smaller than symbol if not visible).

667

668 Fig. 9. Energy profile of the most thermodynamically favorable reaction pathways for aqueous nitrate 669 and nitrite reduction on $\mathrm{Ru}_{18}$ clusters as calculated using PBE0 functional and LANL2DZ $670(\mathrm{Ru}) / 6-31+\mathrm{G}(\mathrm{d}, \mathrm{p})(\mathrm{N}, \mathrm{H}, \mathrm{O})$ basis sets. 


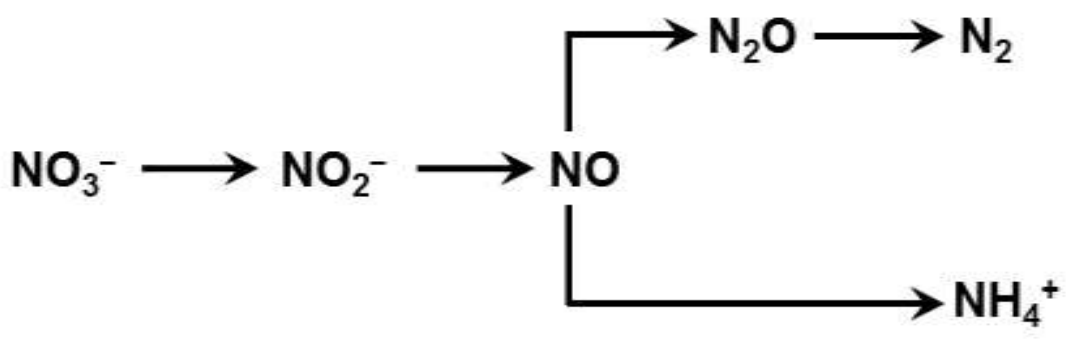

671

672 Scheme 1. Nitrate hydrogenation pathway on Pd-based bimetallic catalysts 


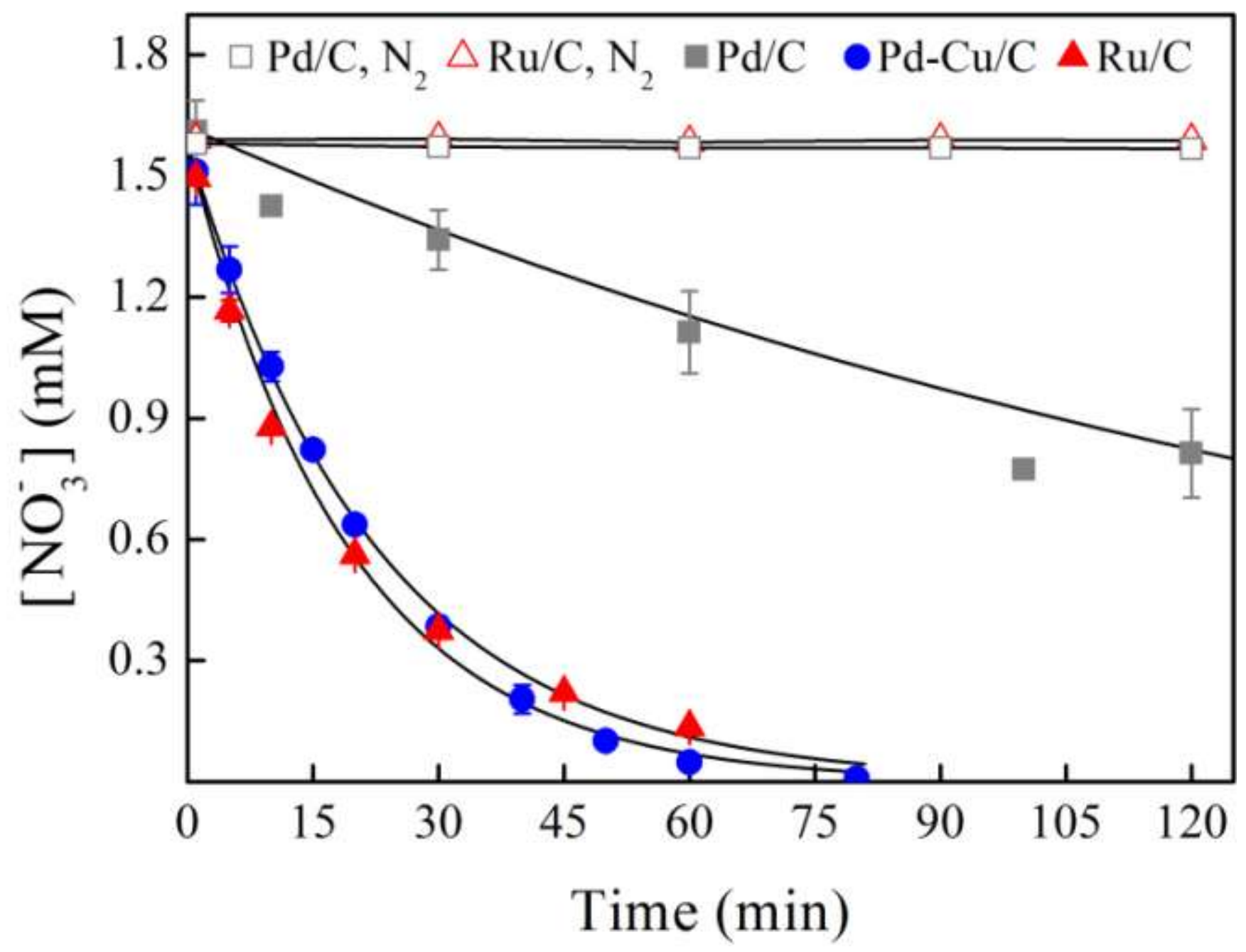

Fig. 1. Measured reaction timecourses for nitrate reduction and first-order model fits on $5 \mathrm{wt} \% \mathrm{Ru} / \mathrm{C}, 5$ $675 \mathrm{wt} \% \mathrm{Pd} / \mathrm{C}$, and $5 \mathrm{wt} \% \mathrm{Pd}-1 \mathrm{wt} \% \mathrm{Cu} / \mathrm{C}$ in the semi-batch reactor system $\left(0.2 \mathrm{~g} \cdot \mathrm{L}^{-1}\right.$ catalyst, $\left[\mathrm{NO}_{3}{ }^{-}\right]_{0}=1.6$ 676 $\mathrm{mM}, 1$ atm $\mathrm{H}_{2}$ continuous sparging except in control experiments where $1 \mathrm{~atm} \mathrm{~N}_{2}$ continuous sparging 678 was used, $\mathrm{pH} 5.0$ maintained by $\mathrm{pH}$ stat, $25 \pm 0.5^{\circ} \mathrm{C}$ ). Error bars represent standard deviations of triplicate reactions. 
Table 1. Properties of catalysts used for nitrate activity test

\begin{tabular}{|c|c|c|c|c|c|c|c|c|c|}
\hline Catalyst & $\begin{array}{c}\text { BET } \\
\text { surface } \\
\text { area } \\
\left(\mathrm{m}^{2} \cdot \mathrm{g}^{-1}\right)\end{array}$ & $\begin{array}{c}\text { Total pore } \\
\text { volume } \\
\left(\mathrm{cm}^{3} \cdot \mathrm{g}^{-1}\right)\end{array}$ & $\begin{array}{c}\text { Average } \\
\text { pore } \\
\text { diameter }^{b} \\
(\mathrm{~nm})\end{array}$ & $\begin{array}{c}\text { Metal } \\
\text { loading } \\
(\mathrm{wt} \%)\end{array}$ & $\begin{array}{c}\text { Metal } \\
\text { dispersion } \\
(\%)\end{array}$ & $\begin{array}{c}\text { Active } \\
\text { surface } \\
(\%)\end{array}$ & $\begin{array}{c}\text { Chemisorption } \\
\text { particle size } \\
(\mathrm{nm})\end{array}$ & $\begin{array}{c}\text { TEM particle } \\
\text { size } \\
(\mathrm{nm})\end{array}$ & $\begin{array}{c}\mathrm{TOF}_{0} \\
\left(\min ^{-1}\right)^{\mathrm{c}}\end{array}$ \\
\hline $\mathrm{Ru} / \mathrm{C}$ & 859.7 & 0.74 & 3.46 & $5.38^{\mathrm{d}}$ & 38 & 32 & 3.5 & $2.2 \pm 0.8$ & $2.1 \pm 0.2$ \\
\hline $\mathrm{Ru} / \mathrm{Al}_{2} \mathrm{O}_{3}$ & 93.1 & 0.36 & 15.34 & $5^{\mathrm{e}}$ & 15 & 9 & 8.8 & $8.1 \pm 3.0$ & $2.4 \pm 0.5$ \\
\hline $\mathrm{Pd} / \mathrm{C}$ & 856.9 & 0.72 & 3.35 & $6.24^{\mathrm{d}}$ & 17 & 19 & 6.5 & $4.1 \pm 2.2$ & $0.42 \pm 0.07$ \\
\hline $\mathrm{Pd} / \mathrm{Al}_{2} \mathrm{O}_{3}$ & 98.4 & 0.24 & 9.69 & $5.85^{\mathrm{d}}$ & 16 & 15 & 6.9 & $4.2 \pm 1.1$ & $N R^{f}$ \\
\hline
\end{tabular}

$680{ }^{a}$ Adsorption total pore volume at $\mathrm{P} / \mathrm{P}_{0}=0.97$. ${ }^{\mathrm{b}}$ Calculated from total pore volume and BET surface area. ${ }^{\mathrm{c}}$ Calculated based on active surface. ${ }^{\mathrm{d}}$ Measured by

681 ICP-OES analysis. ${ }^{\mathrm{e}}$ Nominal value provided by supplier. ${ }^{\mathrm{f}}$ No reaction observed.

682 

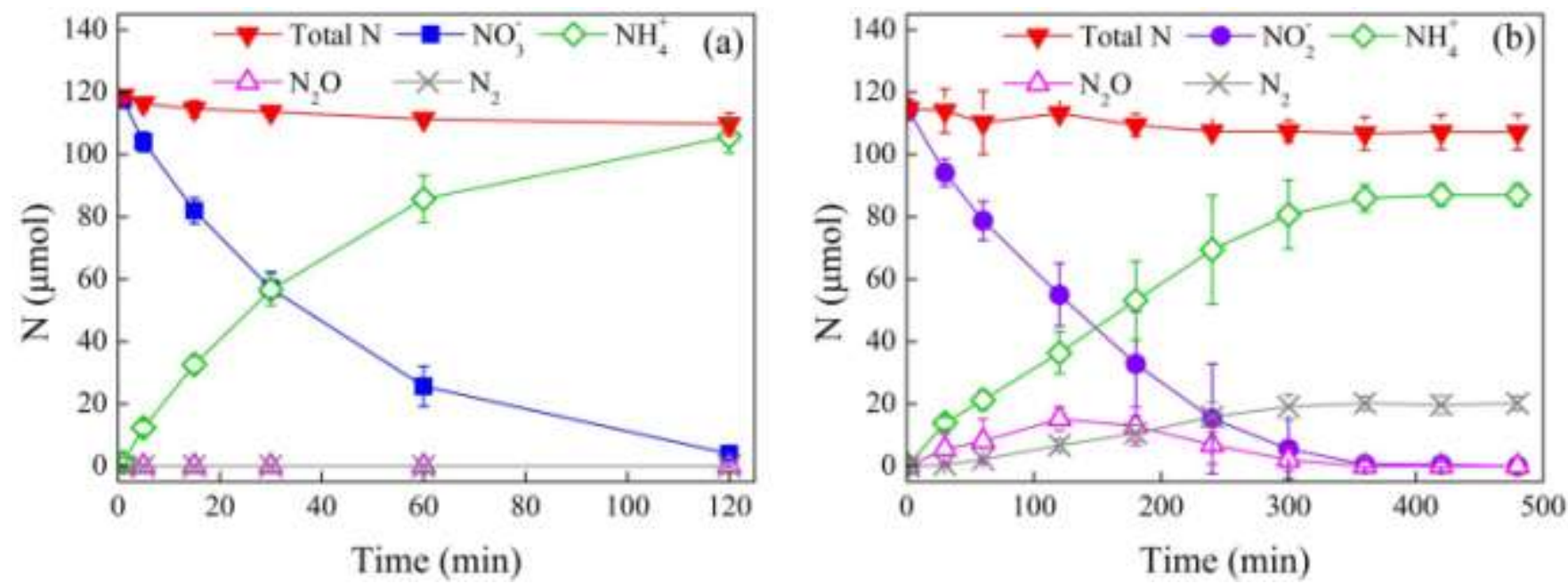

684 Fig. 2. Timecourses showing aqueous and gaseous intermediates and products during Ru/C-catalyzed 685 reduction of ${ }^{15} \mathrm{~N}$-labeled (a) nitrate and (b) nitrite monitored in closed-bottle batch systems $\left(0.2 \mathrm{~g} \cdot \mathrm{L}^{-1}\right.$ 686 catalyst, $\left[{ }^{15} \mathrm{NO}_{3}{ }^{-}\right]_{0}$ or $\left[{ }^{15} \mathrm{NO}_{2}^{-}\right]_{0}=1.6 \mathrm{mM}$, initially 1 atm $\mathrm{H}_{2}$, pH 5.5 buffered by $40 \mathrm{mM}$ MES, $21 \pm$ $6871^{\circ} \mathrm{C}$ ). Error bars represent standard deviations of triplicate reactions (smaller than symbol if not visible). 

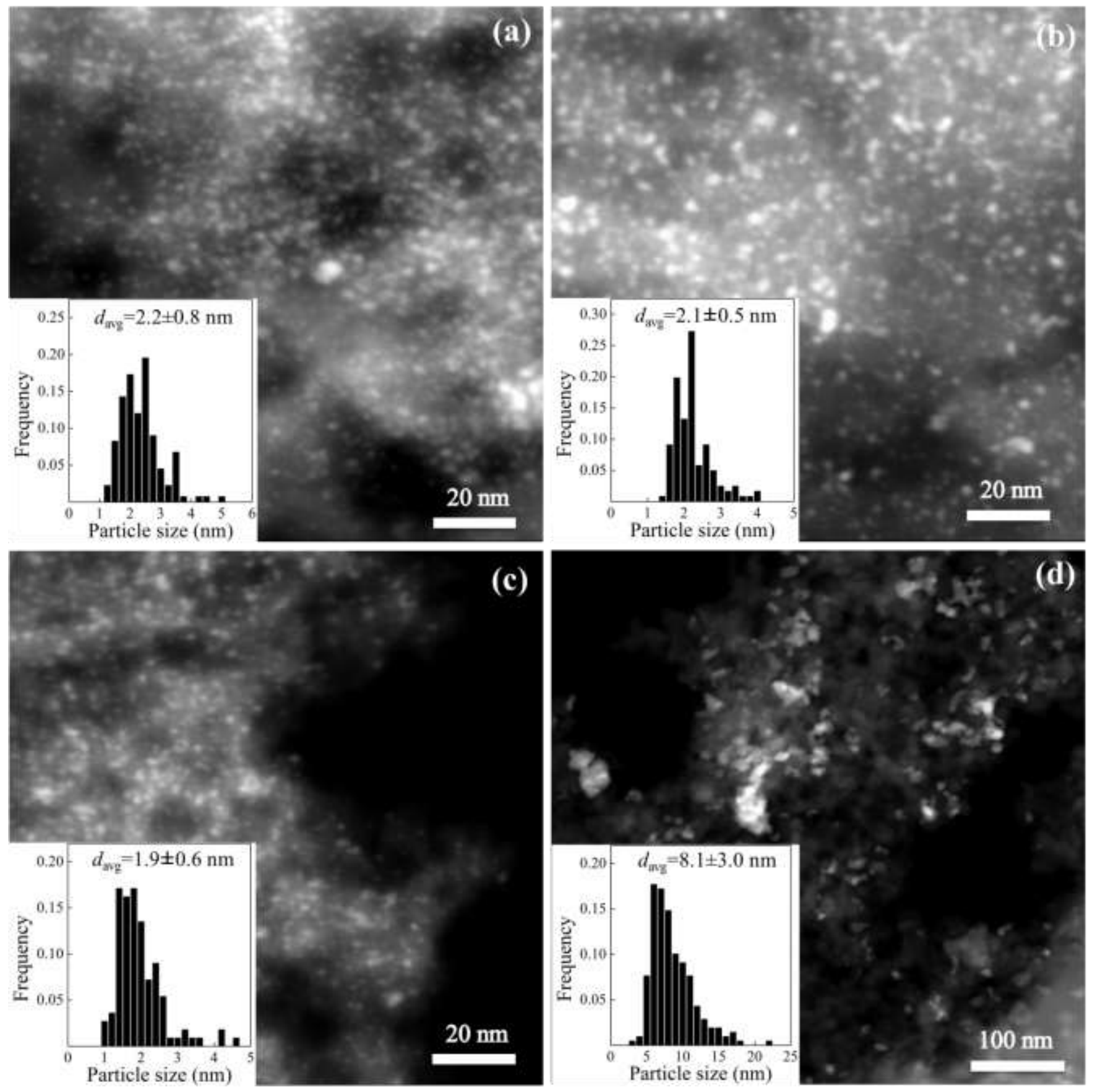

Fig. 3. HAADF-STEM images of (a) ex situ $\mathrm{H}_{2}$ pretreated $\mathrm{Ru} / \mathrm{C}$, (b) $\mathrm{Ru} / \mathrm{C}$ after re-use experiment, (c) 690 as-received $\mathrm{Ru} / \mathrm{C}$ and (d) ex situ $\mathrm{H}_{2}$ pretreated $\mathrm{Ru} / \mathrm{Al}_{2} \mathrm{O}_{3}$. The insets show Ru particle size distributions. 


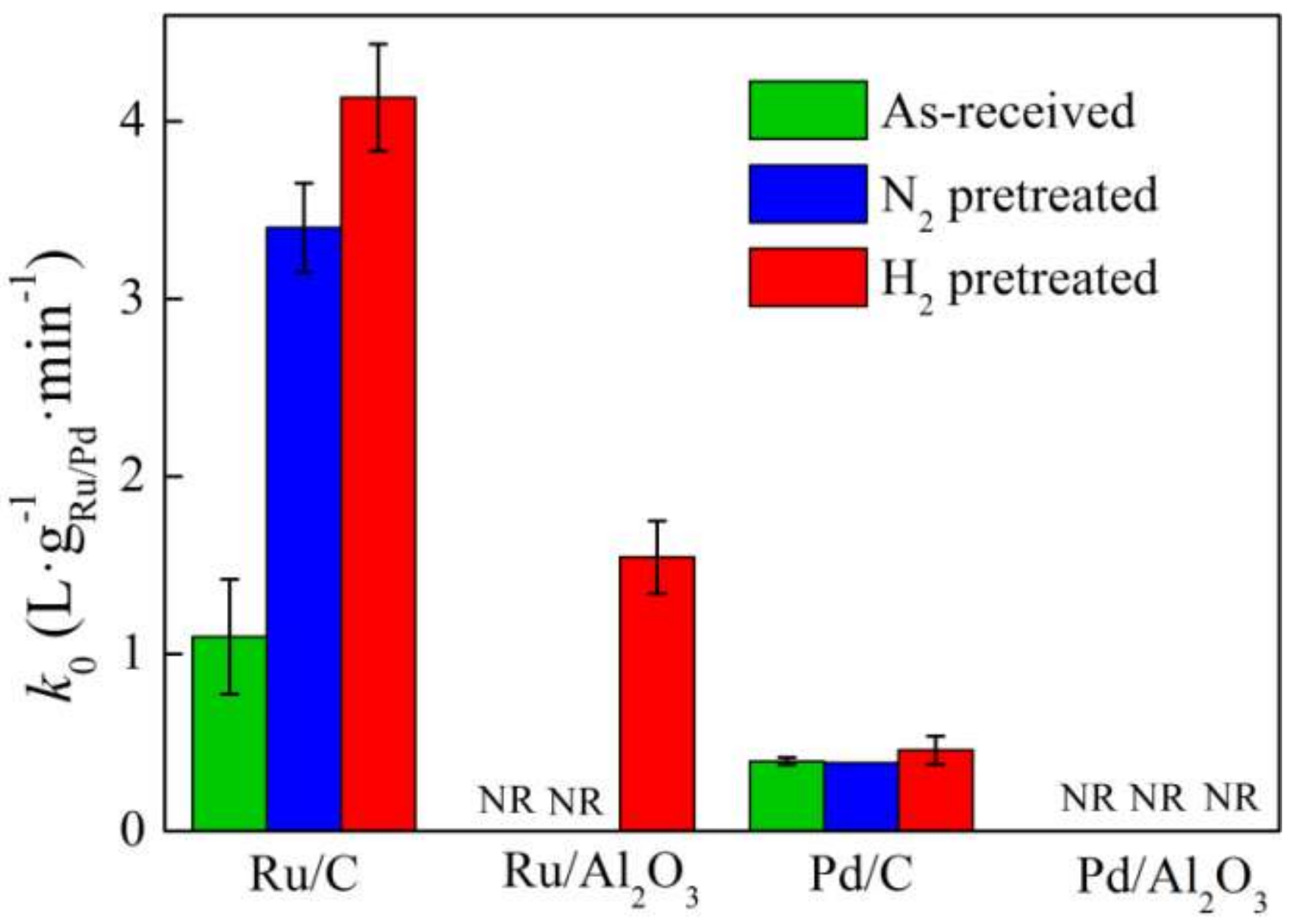

691

692

693

694

695

696

Fig. 4. Influence of catalyst pretreatments (as-received catalyst or ex situ pretreated in flowing $\mathrm{H}_{2}$ or $\mathrm{N}_{2}$ at $350{ }^{\circ} \mathrm{C}$ for $\left.2 \mathrm{~h}\right)$ on reactivity with aqueous nitrate $\left(0.2 \mathrm{~g} \cdot \mathrm{L}^{-1}\right.$ catalyst with nominal $5 \mathrm{wt} \% \mathrm{Ru}$ or $\mathrm{Pd}$, $\left[\mathrm{NO}_{3}{ }^{-}\right]_{0}=1.6 \mathrm{mM}, 1 \mathrm{~atm} \mathrm{H}_{2}$ continuous sparging, $\mathrm{pH} 5.0$ maintained by automatic $\mathrm{pH}$ stat, $25 \pm 0.5^{\circ} \mathrm{C}$ ).

Error bars represent standard deviations of triplicate measurements (smaller than symbol if not visible). $\mathrm{NR}=$ no reaction observed. 

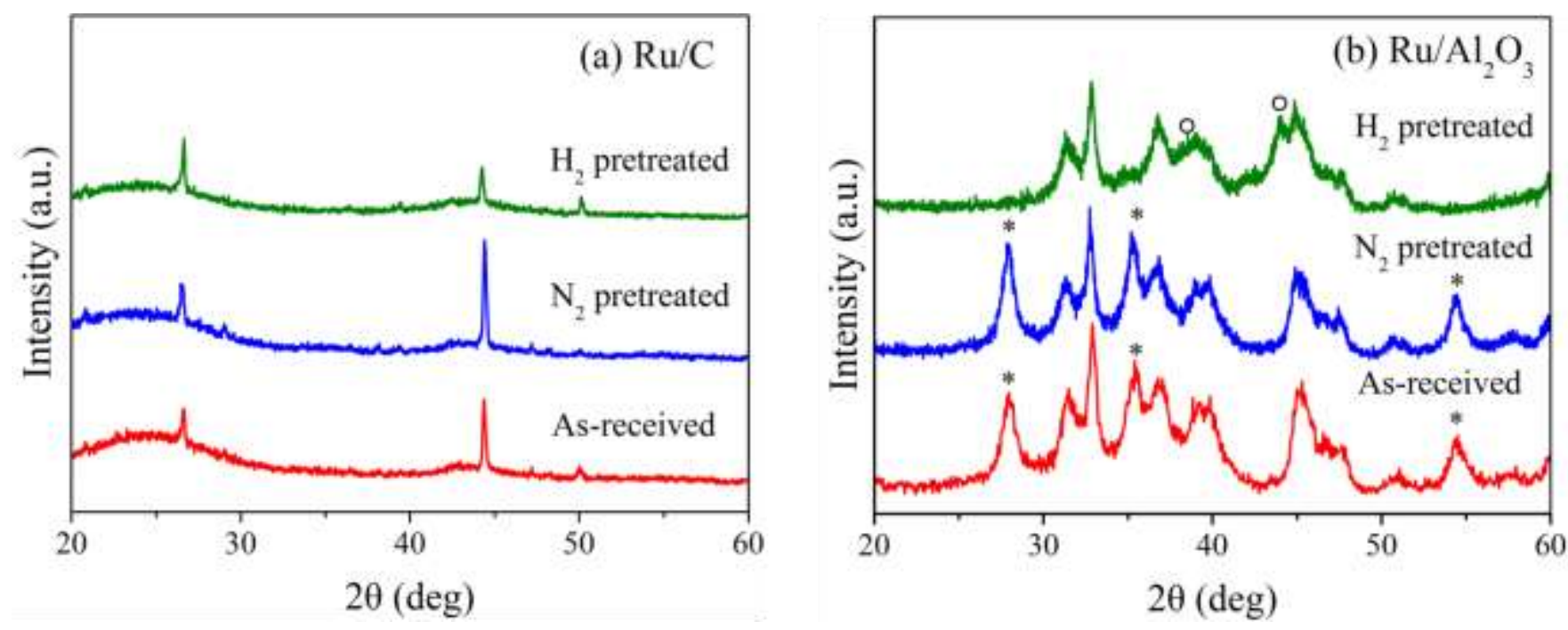

698 Fig. 5. XRD patterns of (a) $\mathrm{Ru} / \mathrm{C}$ and (b) $\mathrm{Ru} / \mathrm{Al}_{2} \mathrm{O}_{3}$ collected after different $e x$ situ pretreatments. Peaks 699 assigned to $\mathrm{Ru}$ metal ( $\mathrm{O})$ and $\mathrm{RuO}_{2}\left(^{*}\right)$ are indicated. 


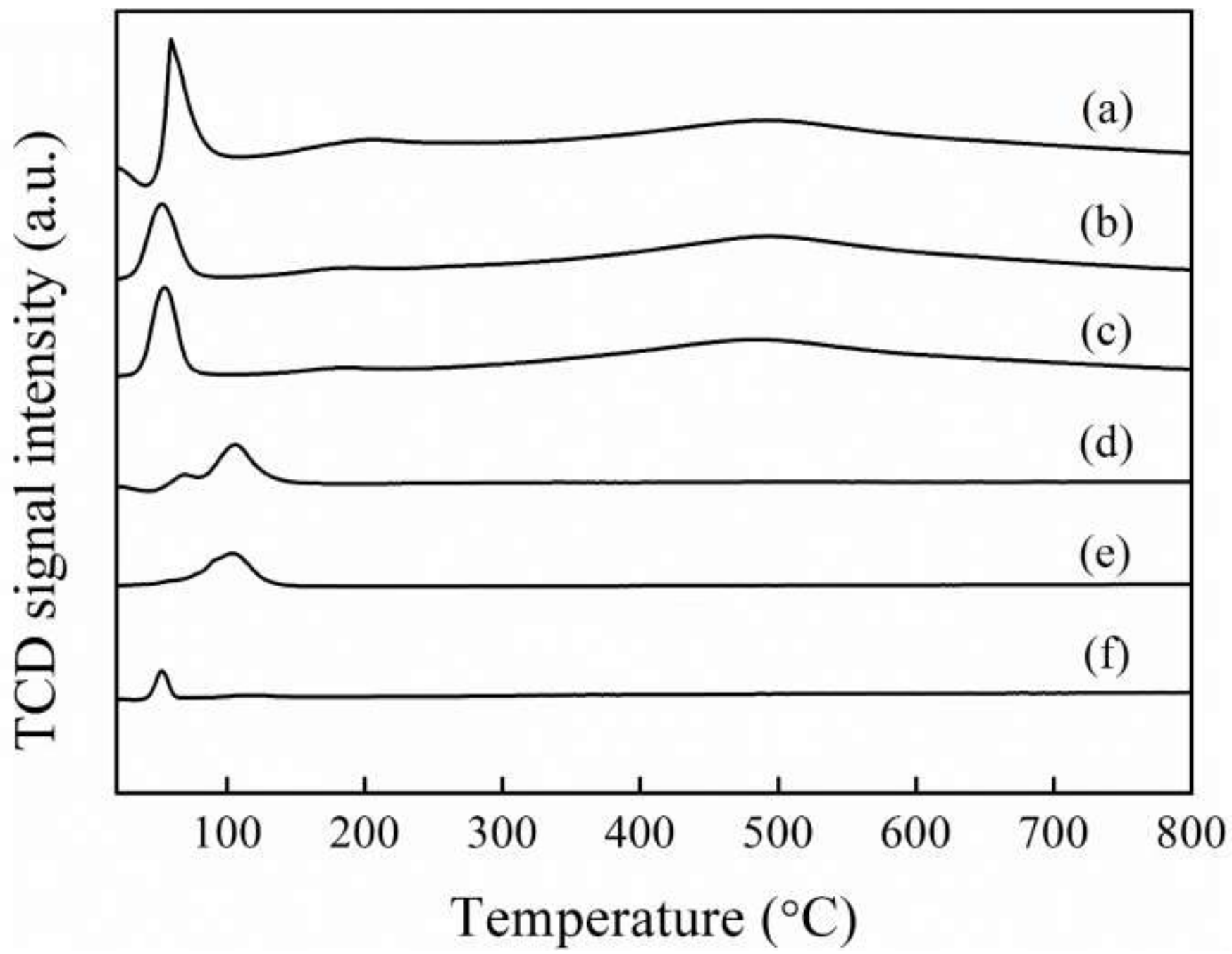

Fig. 6. TPR profiles of (a) as-received $\mathrm{Ru} / \mathrm{C}$, (b) ex situ $\mathrm{N}_{2}$ pretreated $\mathrm{Ru} / \mathrm{C}$, (c) ex situ $\mathrm{H}_{2}$ pretreated $702 \mathrm{Ru} / \mathrm{C}$, (d) as-received $\mathrm{Ru} / \mathrm{Al}_{2} \mathrm{O}_{3}$, (e) ex situ $\mathrm{N}_{2}$ pretreated $\mathrm{Ru} / \mathrm{Al}_{2} \mathrm{O}_{3}$, and (f) ex situ $\mathrm{H}_{2}$ pretreated $703 \mathrm{Ru} / \mathrm{Al}_{2} \mathrm{O}_{3}$. TCD signals are normalized with sample mass. 

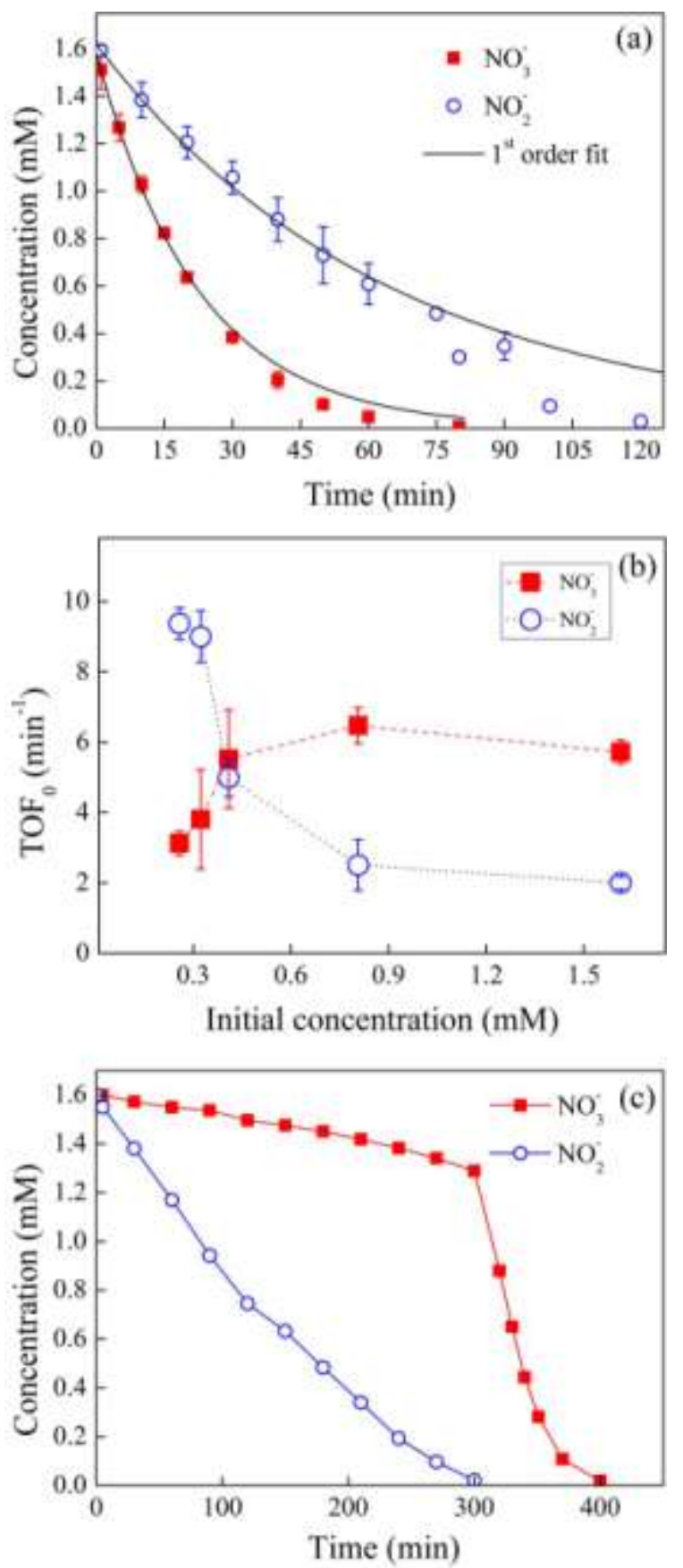

Fig. 7. (a) Comparison of $\mathrm{Ru} / \mathrm{C}$-catalyzed nitrite reaction kinetics with nitrate reaction at standard 706 conditions $\left(0.2 \mathrm{~g} \cdot \mathrm{L}^{-1} \mathrm{Ru} / \mathrm{C},\left[\mathrm{NO}_{3}{ }^{-}\right]_{0}\right.$ or $\left.\left[\mathrm{NO}_{2}^{-}\right]_{0}=1.6 \mathrm{mM}\right)$. (b) $\mathrm{TOF}_{0}$ of $\mathrm{Ru} / \mathrm{C}$-catalyzed nitrate and nitrite 707 reduction as a function of initial concentration of the target oxyanion $\left(0.2 \mathrm{~g} \cdot \mathrm{L}^{-1} \mathrm{Ru} / \mathrm{C}\right)$. (c) Measured 708 timecourses for the simultaneous reduction of nitrate and nitrite added to a suspension containing $\mathrm{Ru} / \mathrm{C}$ 709 $\left(0.2 \mathrm{~g} \cdot \mathrm{L}^{-1}\right.$ catalyst, $\left.\left[\mathrm{NO}_{3}\right]_{0}=\left[\mathrm{NO}_{2}^{-}\right]_{0}=1.6 \mathrm{mM}\right)$. Other conditions include 1 atm $\mathrm{H}_{2}$ continuous sparging, $710 \mathrm{pH} 5.0$ maintained by automatic $\mathrm{pH}$ stat, and $25 \pm 0.5^{\circ} \mathrm{C}$. Error bars in panels a-b represent standard 711 deviations of triplicate measurements. 

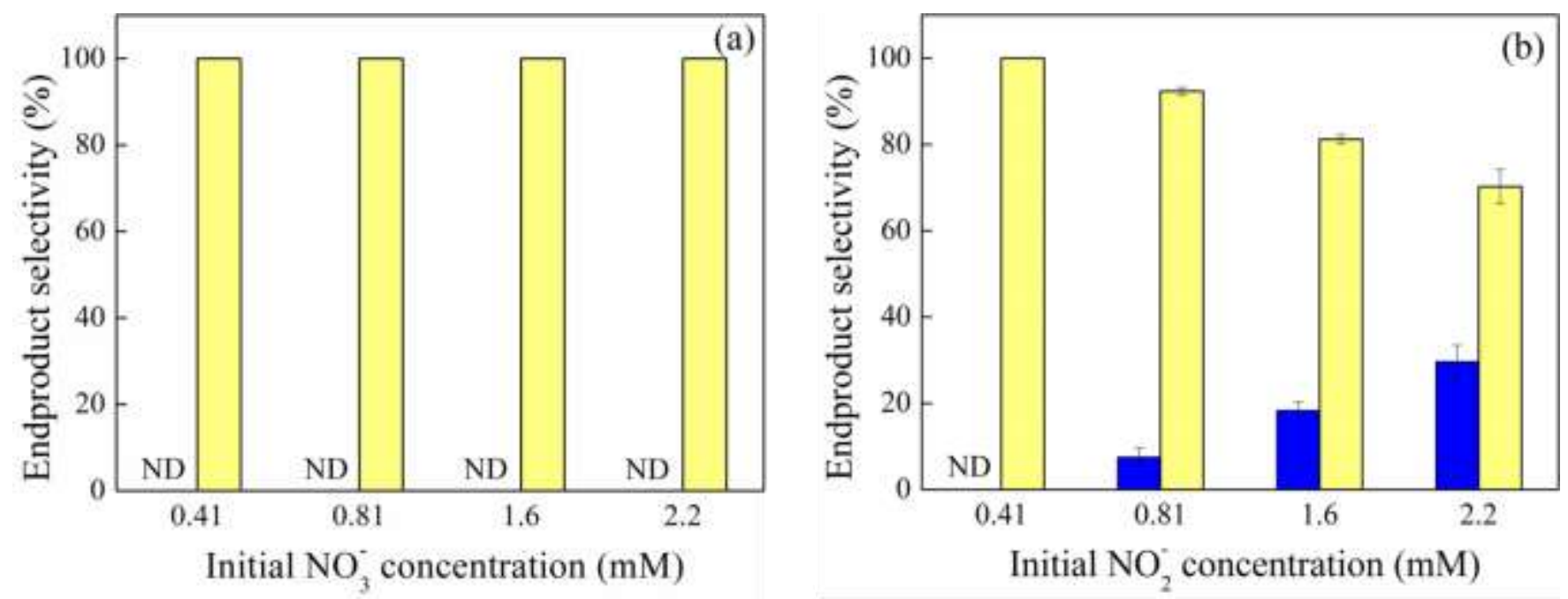

Fig. 8. Effect of initial (a) nitrate and (b) nitrite concentration on $\mathrm{NH}_{4}{ }^{+} / \mathrm{N}_{2}$ product selectivity (yellow: $714 \mathrm{NH}_{4}{ }^{+}$; blue: $\mathrm{N}_{2}$ ). Product selectivity is based on percent molar $\mathrm{N}$ concentration. Error bars represent 715 standard deviations of triplicate measurements (smaller than symbol if not visible). 


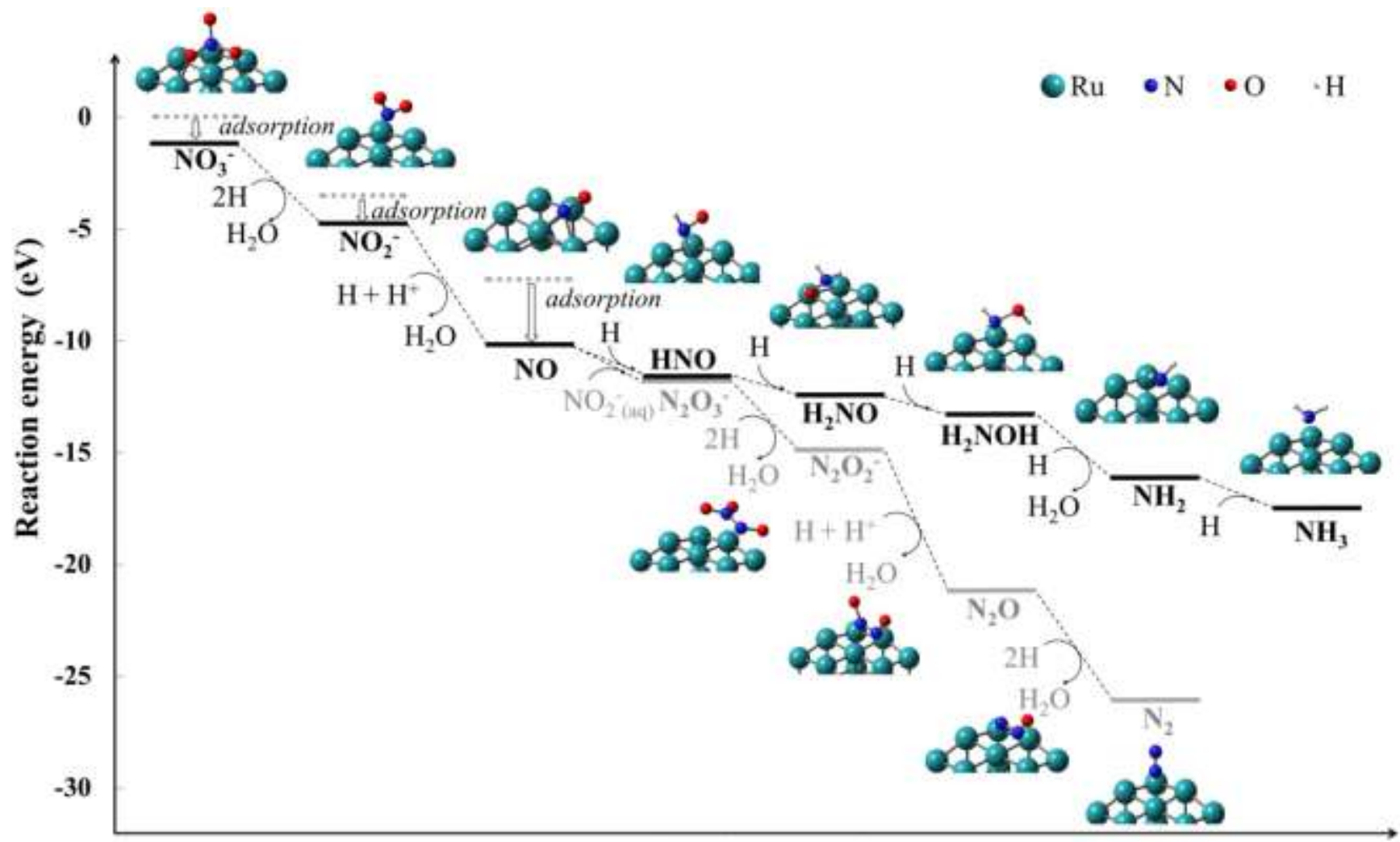

\section{Reaction coordinate}

717 Fig. 9. Energy profile of the most thermodynamically favorable reaction pathways for aqueous nitrate 718 and nitrite reduction on $\mathrm{Ru}_{18}$ clusters as calculated using PBE0 functional and LANL2DZ $719(\mathrm{Ru}) / 6-31+\mathrm{G}(\mathrm{d}, \mathrm{p})(\mathrm{N}, \mathrm{H}, \mathrm{O})$ basis sets. 